\title{
Characteristic analysis of geochemical \\ exploration data
}

by

Joseph Moses Botbol, Richard Sinding-Larsen,

Richard B. McCammon, and Garland B. Gott

U. S. GEOL. SURVEY OPEN FILE REPORT

$$
\text { OF } 77-349
$$




\section{Contents}

Pape

Introduction . . . . . . . . . . . . . . . . . 1

Purpose . . . . . . . . . . . . . . . . . . 2

Acknowledgements . . . . . . . . . . . . . ?

Characteristic Analysis Methodology . . . . . . . . . 3

Second derlvative surface..... . . . . . . . 3

Boolean representation . . . . . . . . . . . 4

"Favorable" model formulation. . . . . . . . . 5

Regional cell evaluation . . . . . . . . . . . 7

CHARAN - characteristic analysis computer propram . • 7

Coeur d'Alene district, Idaho, U.S.A. . . . . . . . 8

Data description .............. . . 10

Data analysis . . . . . . . . . . . . . 11

Conclusions . . . . . . . . . . . . . . . . . 24

References cited . . . . . . . . . . . . . . . . 25

Appendix . . . . . . . . . . . . . . . . . 27 
Figure 1. Hypothetical geochemical profile showing areas above local inflection points (second derivative negative) labelled 1 and other locations labelled 0................. 33

Figure 2. Model of four variables for five cells. . . . . . 34

Figure 3. Sample calculation of product matrix for binary array in Figure 2............ . 35

Figure 4. Degree of association between region cell and model.. 36 Figure 5. Flowchart of interactive characteristic analytic technique . . . . . . . . . . . . 37

Figure 6. Index map of Idaho showing location of the Coeur d'Alene mining district . . . . . . . . 38

Figure 7. Generalized geologic map of the Coeur d'Alene district (modified from Hobbs and other, 1965 , pls. 3-5)............. . . 39

Figure 8. Rock geochemical sampling sites, Coeur d'Alene mining district, Idaho. . . . . . . . . . 40

Figure 9. Locations of 12 model areas in the Coeur d Alene mining district, Idaho. ........... 41

Figure 10. Degrees of association of the Coeur d'Alene mining district with the Atlas model area . . . . 42 
Figure 11. Degrees of association of the Coeur d'Alene mining district with the Black Bear model area . . . . . . . . . . . . . 43

Figure 12. Degrees of association of the Coeur d'Alene mining district with the Bunker Hill model area .................

Figure 13. Degrees of assoclation of the Coeur d Alene mining district with the Day Rock model area. .

Figure 14. Degrees of association of the Coeur d'Alene mining district with the Galena model area...

Figure 15. Degrees of association of the Coeur d'Alene mining district with the Hecla model area....

Figure 16. Degrees of association of the Coeur d'Alene mining district with the Hercules model area.. 48

F1gure 17. Degrees of association of the Coeur d'Alene mining district with the Silver Summit model area . . . . . . . . . . . . .

Figure 18. Degrees of association of the Coeur d Alene mining district with the Sunshine model area..

Figure 19. Degrees of association of the Coeur d'Alene mining district with the Snowstorm model area. . 51

Figure 20. Degrees of association of the Coeur d'Alene mining district with the Star Morning model area. 
Figure 21. Degrees of association of the Coeur

d'Alene mining district with the Tamarack model area ............ 53

Figure 22. Degrees of association of the Coeur d'Alene mining district with the aggregate mineralization model area. . . . . . . 54

Figure 23. Structural restoration of the Osburn and Dobson Pass faults showing probable original positions of aggregate mineralization model cells and associated most similar non-model cells............... 55 
Table

Page

Table 1. Characteristic weights of 11 elements in 13 model areas. . . . . . . . . . . . . . . 


\section{Introduction}

There now exist a number of numerical methods readily available for the treatment of exploration peochemical data (McCammon, 1974). What most methods have in common is the assumption that the areas of greatest interest will be reflected by the highest values of the measured variables. Thus, high measurement amplitude is more favorable than low measurement amplitude. These methods also place considerable emphasis on the product-moment correlation between the variables based on large numbers of samples. The spatially dependent technique described in this report differs from these methods in that importance is placed on measured values which differ locally from neighboring locations and on correlations between variables based on a relatively small number of observations.

The method is designed to treat geochemical variables that have been transformed to binary form where "l" means that a variable is "favorable" in the sense that the location is favorable for exploration and "O" means that a variable is of indeterminate value for determining the favorability. Favorabillty is defined on a local basis and a variable is considered favorable at a location if the measured value of the variable is higher than the surrounding values observed for that variable. 
For variables represented in binary form, it is the union of intersections that expresses the quantitative relationship between variables and not the correlation coefficient. Such a representation eliminates many of the problems associated with the other methods which are amplitude dependent in terms of spatial variation.

\section{Purpose}

The purpose of this report is to present the methodology of characteristic analysis applied to exploration geochemical data.

The geochemical data used represent information collected in an area with known wineralization, and, therefore, the results obtained by characteristic analysis could be compared with the existing interpretations.

Application of the methodology to data for a mix of disciplines such as remote sensing, geophysics and geologic mapping is not within the scope of this report. However, progress has been made in this direction and will be the subject of a future report. Furthermore variables and models used in the geochemical example are intended as a test of the methodolory and not to establish a prospecting scheme for the area covered by the data. 


\section{Acknowledpements}

The authors gratefully acknowiedge the Directors of both the U.S. Geological Survey and the Norwegian Geologicai Survey for their permission to coilaborate in this research.

Messrs. T. Billings, J. Cathraii, R. Nemes, and R. Bowen, of the U.S. Geologicai Survey provided assistance in data preparation interpretation, mathemathicai formulation, and programming.

Characteristic Anaiysis Methodology

There are four concepts invoived with the methodoiorv used in this analysis; two-dimensionai second derivative surface, Boolean transformation, "favorabie" model formuiation, and regionai ceil evaluation.

Second Derivative Surface.--The spatiai distribution of eiementai abundances in sampied material in geochemicai expioration has lonp posed problems of interpretation. Considerable past efforts have been directed toward the recognition of anomaities based on the concept of a threshoid value. Most interpretative techniaues reiy on a priori knowiedge of the geoiogical environment in which the samnies were coilected making, it difficuit in most cases to determine a singie vaiue which applies over an entire repion. Traditionaily, the distribution of vaiues is partitioned into twc popuiations, the background popuiation and the target noDuiation. Aithough such a partition can be made, it is not 
necessarily the most effective in terms of exploration. It is logical to assume that although part of a region may be considered totally in background, anomalies can exist within the conventionally defined range of background values. In recognition of this fact, the authors have elected instead to define the term "anomaly" as any value higher than its immediate neighbors, or all points which lie above a point of inflection as defined by a mathematical surface which represents the spatial distribtuion of measured values for a particular element. A point of inflection occurs whenever the second derivative of the surface is equal to zero. Local maxima have second derivatives which are less than zero and these are considered as anomalies.

This is illustrated in Figure 1 for a typical geochemical profile taken from a two-dimensional surface. Boolean representation.--George Boole (1815-1864), a British mathematician, pioneered the use of binary logic in problem solving. Boolean representation refers to the designation of items of positive interest as "l's," and the designation of items of undefined interest as " 0 's." It is this binary designation of "I" or "O" of a location that is the key to the multivariate structure of characteristic analysis. Where a cell or location has a negative second derivative for a particular variable, it is labelled " 1 ," and is of interest because the values within the cell are higher than the values in the neighboring cells. The " $0^{\circ} \mathrm{s}^{\prime \prime}$ represent all other data. 
For those variables with known negative anomaly representation (i.e. concentration directly related to distance from mineralization) simple reversal of binary notation is possible.

Spatial patterns expressed in binary form are amplitude independent in that the height of an anomaly has no influence on an area being treated as anomalous. This type of representation yields maps that indicate only those areas that have values higher than their immediate neighbors and it is these areas which are of major interest in exploration.

"Favorable" model formulation--a "weighted fingerprint."-After having generated a Boolean array for each variable in a region, the next step is to establish criteria that define designated model areas in which each cell of a repion can be compared. Models in characteristic analysis are formulated by selecting variables for a subset of cells within a region. Having chosen the cells which define the model, it is necessary to determine the relative weight or contribution of each variable in the model.

Consider a model area of 4 variables for each of 5 cells shown in Figure 2. 
If the degree of common occurrence for each variable with other variables is tabulated in an array, the array represents the total common occurrence of all the variables. This array is a "product matrix" because it is obtained by multiplying the original binary occurrence matrix by its transpose. This is shown in Figure 3.

- Each row of the product matrix represents the degree of common occurrence between each variable and the other variables. If one considers the rows of the product matrix as vectors, the length of each vector is equal to the souare root of the sum of the squares of the components. If these vectors are regarded as each being at right angles to each other in n-dimensional space where $n$ equals the number of variables, the vector which maximizes the projections of the variable vectors is the elgenvector associated with the largest characteristic root of the product matrix.

For convenience, its length is set arbitrarily to unity. The coefficients of the eigenvector define the weights associated with the variables selected for a particular model. For detailed explanation of some basic techniaues used in characteristic analysis, the reader is referred to Botbol (1971). 
The details of the computation of the eigenvector associated with the largest characteristic root or eigenvalue of the product matrix is provided in the Appendix.

Regional cell evaluation.--After the weights of the variables which comprise a model have been constructed, there remains the computation of the degree of association between each region cell and the model. This is accomplished by multiplying the binary vector that represents the variables of each region cell with the characteristic vector of the model. Figure 4 shows this computation for a region cell compared with the model example from Figure 3.

\section{CHARAN - Characteristic Analysis Computer Program}

The program CHARAN (CHARacteristic ANalysis) is designed to perform characteristic analysis on data which have been transformed in binary form. Thus, before executing CHARAN, the user must transform the original data by taking the second derivative or by other means define the variables as 1 or 0 . For a region, the data cells are numbered sequentially from left to right, beginning at the lower left portion of the area. In order to conserve core storage necessary for implementation, the "l's" and "0's" along with "2"s," which are used for missing data, are represented as multiples of integral powers of 3 in the data matrix. In this way, depending on the word size of the host computer, one word of the data matrix is capable of storing up to 20 binary encoded variables. The present version of CHARAN accommodates 2,000 cells and 40 variables. 
CHARAN was written in such a way that the user is guided through an analysis for one model at a time. Throughout the analysis, the user is provided options that allow changes or modification in the model. Once the cells and variables are selected, the characteristic vector is calculated. At this point the user can redefine the model or continue with regional cell evaluation. The output from this calculation can be used as input to a 3-dimensional perspective graphics display. The output of the regional cell evaluation is used primarily, however, for selecting the partitions for displaying the degree of association of each region cell with the model in the form of an outline map which displays the degree of association for each cell. Such maps are shown in Figures 10 through 22.

Figure 5 is a flow chart of the characteristic analysis procedure.

Coeur d'Alene District, Idaho, U.S.A.

Characteristic analysis was applied to geochemical data from the Coeur d'Alene district, Idaho, U.S.A. Figure 6

is an index map

showing the location of the study area. 
Figure 7 is a seneraiced geoiogic map of the area. The sampied area comprises approximateiy 200 souare miles of Precambrian terrane which inciudes the iargest siiver producing district in the United States. Many extensive geoiogic investigations have been undertaken in this area (Hobbs et al., 1965, Clark, 1971, Harrison, 1972, Gott and Botbol i973, 1975). In particuiar the geochemicai studies (Gott and Botbol 1973, 1975) have provided a comprehensive picture of surficiai elementai distribution. The amount of geochemical data and the supportive interpretative information ied to the seiection of this district as the exampie on which to apply characteristic anaiysis. The major structurai features include two E-W transcurrent right lateral faults, the Osburn and Placer Creek, that trisect the district (Figure 7). An approximateiy $\mathrm{N}-\mathrm{S}$ normal fauic in the northern part of the district, the Dobson pass fault, intersects the Osburn fauit so as to divide the northern part of the district into two parts; the hanging wall to the west, and the footwall to the east. Immediately east of the Dobson Pass fauit, there are two major granitlc intrusives. The faults and the intrusives are the major structural elements used as a general framework for the description of the resuits of this study. The geoloric framework and the areas seiected as modeis used in this anaiysis are shown in Figures 7 and 9. 


\section{Data Description}

The locations of approximately 8,000 rock samples collected from the Coeur d'Alene district are shown in Figure 8. Each sample was chemically analyzed for 30 elements by semi-quantitative spectrographic methods, and for 10 elements by atomic absorbtion, or colorimetric methods. To facilitate computation, the district was divided into square cells, 1,500 feet on a side, and the highest data value for each variable within 2,000 feet of each cell center was plotted at the center. The highest value was selected instead of an average because of the desire to retain high geochemical variability. The district was gridded in a 29 row by 66 column matrix.

of the 40 variables the following 11 elements were selected for use in this analysis:

$\mathrm{Hg}, \mathrm{Te}, \mathrm{Cu}, \mathrm{Pb}, \mathrm{Zn}, \mathrm{Ag}, \mathrm{Cd}, \mathrm{As}, \mathrm{Sb}, \mathrm{Na}$, and $\mathrm{K}$. These eleven elements contain most of the sulfide signature of the silver-bearing deposits and also reflect the influence of acid intrusives. Twelve major mineralized areas were selected as models. A thirteenth model was constructed using the cells for the 12 original models. This was considered the "agqregate mineralization" model. The models were selected on the basis of known productive areas. The idea was to "fingerprint" known productive areas with respect to a fixed set of geochemical elements whose individual distributions were reasonably well defined. 


\section{Data Analysis}

Each of the 13 models was characterized with respect to the same 11 elements. Table 1 shows the characteristic weights for the 11 elements derived from the product matrix for each of the 13 models.

Table 1 also shows, for each model: 1) the number of model cells, the total number of $1^{\text {s }}$ (all elements considered), and the eigenvalue associated with each model. The ratio of the eigenvalue and the total number of $1^{\prime} \mathrm{s}$ indicate the degree of anomaly overlap. Low overlap reflects the independence of cells within the model and this implies poor model construction with respect to variable and/or cell selection. It does not mean, however, that the variables which were selected are unimportant, only that collectively, the combination of cells and/or variables does not constitute a diagnostic "fingerprint."

Scalar multiplication of the region cell vectors by the model cell characteristic vectors produced arrays of ndegrees of association" between region cells and the various models. A frequency distribution was generated for each model versus region cell comparison.

Four classes were arbitrarily selected to depict the ordinal association between region cells and the different models. The histograms are presented in Figures 10 through 22. 
The following text describes each of the 13 model areas with respect to the most significant variable weights, similarities to other models, and anomalous non-model associations. The anomalies are defined as region cells with the highest degree of association with the specified model. Reference to geologic features is confined to the major structural framework consisting of the Osburn, Placer Creek, and Dobson Pass faults, and the two granitic intrusives occurrine immediately east of the Dobson Pass fault.

Atlas model.--The Atlas model is composed of 13 model cells, and is located in the east central part of the district between the Osburn and the Placer Creek faults. Arsenic followed by, $\mathrm{Sb}, \mathrm{Te}$, and $\mathrm{Hg}$ are the most strongly weighted components of the model vector. The model has high degrees of association with the Sunshine, Silver Summit, Galena, and Star Morning models. There are 4 anomalies not associated with other model areas. Three of these lie parallel to and immediately north of the Osburn fault, and the $4 \mathrm{th}$ lies in the southeast corner of the district. The results of the analysis of this model are shown in figure 10 . 
Black Bear model.--The Black Bear model is composed of 7 cells, and is situated immediately southeast of the southernmost intrusive. In order of decreasing importance, the most significant variables are $\mathrm{Sb}, \mathrm{As}, \mathrm{Ag}$, and $\mathrm{Pb}$. The model has high degrees of association with the Bunker Hill, Sunshine, Silver Summit, Galena, Star Morning, and the Atlas models. There are 11 non-model anomalies. Four of these lie parallel to and immediately north of the Osburn fault, three are located in the south and west central part of the region near the trace of the Placer Creek fault, three lie in the hanging wall of the Dobson Pass fault (west of the fault trace), and one is located in the southeast corner of the district. The results of the analysis of this model are shown in figure 11 . 
Bunker Hill model. - The Bunker Hill model is composed of 12 cells, and is situated along the trace of the 0sburn fault in the west central part of the district. In order of decreasing importance, the most significant model variables are $\mathrm{Na}$ and $\mathrm{Pb}$. $\mathrm{Hg}, \mathrm{Zn}, \mathrm{Ag}, \mathrm{Cd}, \mathrm{As}$, and $\mathrm{Sb}$ are equally ranked and are slightly lower in value than $\mathrm{Na}$ and $\mathrm{Pb}$. The model has high degrees of association with the Sunshine, Silver Summit, and Star Morning models. There are 4 non-model anomalies. One lies immediately north of the Osburn fault in the east central part of the district. One lies in the north central part of the region, and is west of the Dobson Pass fault. One lies immediately adjacent to the trace of the Dobson Pass fault in the footwall and north of the southernmost intrusive. One lies in the southeast corner of the district. The results of the analysis of this model are shown in Figure 12. 
Dayreck model. -The Dayrock model is composed of 6 cells and is situated in the hanging wall of the Dobson Pass fault immediately west of the southernmost intrusive. $\mathrm{Sb}, \mathrm{Zn}$ and $\mathrm{Cu}$ are equally weighted, and are the only non-zero variable components in the model. The model has high degrees of association with the Silver Summit, Galena, Black Bear, and the Atlas models. There are 10 non-model anomalies. Four are parallel to the Osburn fault, four appear to be roughly associated with the Placer Creek fault, one is in the footwall of the Dobson Pass fault and is northwest of the northernmost intrusive, and one is in the southeast corner of the district. The results of the analysis of this model are shown in Figure 13. 
Galena model.--The Galena model is composed of 4 cells and is situated in the central part of the district between the Osburn and the Placer Creek faults. All non-zero components of the model variables rank equally and these are: $\mathrm{Hg}, \mathrm{Cu}, \mathrm{Pb}, \mathrm{Ag}, \mathrm{Cd}, \mathrm{As}$, and $\mathrm{Sb}$. The model has a high degree of association with the Silver Summit model. There are 2 non-model anomalies, one of which is in the east central part of the district immediately north of the Osburn fault, the other is in the southeast corner of the district. The results of the analysis of this model are shown in Figure 14.

Hecla model.--The Hecla model (Figure 16) is composed of 10 cells and is situated immediately east of the southern most intrusive. In order of decreasing signifance the components of the characteristic vector are: $\mathrm{As}, \mathrm{Hg}, \mathrm{Na}, \mathrm{Pb}$, $\mathrm{Pb}$, and $\mathrm{Ag}$. The model has a high degree of association with the Bunker Hill model, the Sunshine model, and the Star Morning model. There are no significant non-model anomalies. It does not mean, however that there is no value to the model signature. Of importance is the fact that there are 3 mineralized areas that closely resemble this model when evaluated for 11 elements. The results of the analysis of this model are shown in Figure 15. 
Hercules model.--The Hercules model (F́igure 17) is composed of 3 cells and is situated immediately east of the northernmost intrusive. $\mathrm{Pb}, \mathrm{Zn}$, and $\mathrm{Ag}$ are the three non-zero components of the model, all of which are equally weighted. The model is highly similar to the Bunker Hill, Silver Summit, Black Bear, Tamarack, and Star Morning models. There are 18 non-model anomalies: six appear to be related to the Osburn fault, four appear to be related to the Placer Creek fault, two are in the hanging wall of the Dobson Pass fault, five are peripheral to the intrusive bodies, and one is in the southeast corner of the district. The most notable aspect of the non-model anomalies is the peripheral pattern that five of these anomalies show relative to the intrusives. The results of the analysis of this model are shown in Figure 16 . 
Silver Summit model.--The Silver Summit model

is located in the west central part of the district immediately south of the trace of the Osburn fault. It is composed of 6 cells and the following elements rank equally and are the significant components of the model: $\mathrm{Sb}, \mathrm{Cd}, \mathrm{Ag}, \mathrm{Zn}, \mathrm{Pb}, \mathrm{Cu}$, and $\mathrm{Hg}$. The model is quite similar to the Sunshine, Galena, and Bunker Hill models. There are 6 non-model anomalies; one is associated with the Placer Creek fault, one is in the hanging wall of the Dobson Pass fault, and one is in the southeast corner of the district. The results of the analysis of this model are shown in Figure 17.

Sunshine model. - The Sunshine model is located in the west central part of the district between the Osburn and Placer Creek faults. It is composed of 8 cells and $A s$ and $\mathrm{Sb}$ are the principal and equally weighted components of the model. $\mathrm{Zn}$ and $\mathrm{Cu}$ are of second order significance and these are also equally ranked. The model has a high degree of association with the Bunker Hill, Silver Summit, and Star Morning models. There are 2 non-model anomalies, one of which is associated with the Osburn fault, and the other lies in the southeast corner of the district. The results of the analysis of this model are shown in Figure 18. 
Snowstorm model.--The Snowstorm model is composed of 5 cells situated north of the Osburn fault in the east central part of the district. Na and $K$ are the most significant components of the model and are equally ranked. As, $\mathrm{Sb}$, and $\mathrm{Hg}$ are of second order significance and comprise the remainder of the non-zero components. The model is highly similar to the Bunker Hill, Sunshine, Black Bear, and Star Morning models. There are 3 non-model anomalies; one is in line with the Bunker Hill-Sunshine trend and between the Osburn and Placer Creek faults, one is immediately west of the southernmost intrusive and in the hanging wall of the Dobson Pass fault, and the third is in the west central part of the district. The results of the analysis of this model are shown in Figure 19.

Star Morning model.--The Star Morning model is composed of 9 cells and is situated in the east central part of the district immediately north of the Osburn fault. As and $\mathrm{Zn}$ are the most significant components of the model and $\mathrm{Hg}$, $\mathrm{Cu}, \mathrm{Pb}, \mathrm{Ag}$, and $\mathrm{Sb}$ are equally weighted and are of second order importance. The model shows a high degree of association with the Bunker Hill, Sunshine and Silver Summit models. There are 2 non-model anomalies, one of which is associated with the Osburn fault, the other is located in the southeast corner of the district. The results of the analysis of this model are shown in Figure 20 . 
Tamarack model.--The Tamarack model is composed of 9 cells and is situated in the north central part of the district immediately east of the southernmost intrusives. $\mathrm{Pb}$ and $\mathrm{Ag}$ are the primary components of the model vector and $C d$ is of second order significance. The model has a high degree of similarity with the Bunker Hill, silver Summit and Star Morning models. There are 8 non-model anomalies; two are immediately adjacent to and north of the Osburn fault, two straddle the Placer Creek fault, one is in the northern part of the hanging wall of the Dobson Pass fault, one is in the footwall of the Dobson Pass fault immediately north of the southern intrusives, one is southeast of the southernmost intrusive, and one is located in the southeast corner of the district. The results of the analysis of this model are shown in Figure 21 . 
Aggregate Mineralization model. - The aggregate mineralization model is composed of 93 cells and encompasses all previous models including one cell that is shared by the Tamarack and Black Bear models. All elements contribute to the model vector and in order of decreasing significance they are as follows: $\mathrm{Sb}, \mathrm{As}, \mathrm{Pb}, \mathrm{Ag}, \mathrm{Hg}, \mathrm{Cu}, \mathrm{Zn}, \mathrm{Cd}, \mathrm{K}$ and $\mathrm{Na}$, and $\mathrm{Te}$. There are 17 non-model anomalies; sixteen of these have occurred in at least one other model, and one of the anomalies located between the Galena and Silver Summit is unique. Eight of the non-model anomalies are situated. in the vicinity of the Osburn fault with one of these at the intersection of the Dobson Pass and the Osburn faults. Three of the anomalies are situated in the vicinity of the Placer Creek fault. Two of the anomalies are in the footwall of the Dobson Pass fault and north of the intrusives. Two of the anomalies are in the hanging wall of the Dobson Pass fault. One of the anomalies is in the southeast corner of the district. The results of the analysis of this model are shown in Figure 22. 


\section{Structural Restoration}

In order to further test the significance of the total mineralization model anomalies, the non-model anomalies were plotted on a generalized structurally restored map of the Osburn and Dobson Pass faults. The structural restoration is based on Gott and Botbol (1975).

After restoration of the 17 non-model anomalies, three of those that occurred in the footwall of the Dobson Pass fault were transposed beyond the limits of the study area. The remaining fourteen anomalies are shown in Figure 23 together with the restored positions of model component areas and intrusive boundaries. Note the aggregation of anomalies between the restored positions of the model areas. This implies a continuity of mineralization in support of the theory of mineral belt continuity (Gott and Botbol, 1973). 
Individual components of the total mineralized model represent individual mineral belts that may or may not be genetically related. Upon restoration, most of the model components argregate to the southeast of the intrusives. Eight anomalies lie peripheral to and between aggregated model components. This suggests a relation between the non-model anomalous cells and the model cells. If one were to expand the model area boundaries, they would include the eight cells that are computed to be highly associated with the model. The positions of the anomalies associated with the Placer Creek fault remain unchanged, as well as the persistent anomaly in the southeast corner of the district.

The structurally restored version of the aggregate model confirms the sulphide signature and provides intermodelcomponent continuity. It lends credence to both the structural reconstitution and the hynotheses regarding the genesis of the mineralization in the model areas. Conversely, the concordance of all anomalous cells demonstrates the predictive efficiency of characteristic analysis. 
Conciusions

Characteristic anaiysis provides the geoiogist with a method for comparing attributes of a reqion with the attributes of a model. Formuiation of the modei consists in choosing region ceils considered favorabie for a Darticuiar type of mineralization and choosing the variabies which best refiect this mineraitzation. The remaining region cells in the area of interest are then compared to the modei and ciassifled according to the depree of association. Characteristic analysis has been implemented in a time share computino environment so that at any time variables which comprise the model or region celis, which define the model, can be added or subtracted. To date, the authors have been unabie to cause the method to faij under reasonabie conditions. To maximize the predictive efficiency of characteristic anaiysis, however, it is essential that sound geoiogic reasoning be used in the seiection of the variabies and the region ceils.

The designation of "most favorable target areas" in the Coeur difene example aptiy demonstrates the effectiveness of the method. The results which were obtained support the previousiy determined geologic hypotheses regarding the spatial distribtuion of the deposits. In addition, nossibie extension of the boundaries of these deposits is nostuiated.

It is hoped that the presentation of this method wiil encourage other investigators to use characteristic anaivsis in other areas so that the method can evolve by future interchanges of ideas and exampies. 
References cited

Botbol, J.M., 1971, An application of characteristic analysis to mineral exploration: Decision Making in the Mineral Industry, C.I.M. Spec. v. no. 12, pp. 92-99. Clark, A.L., 1971, Strata-bound copper sulfides in the Precambrian Belt Supergroup, northern Idaho and northwestern Montana, in International association of genesis of ore deposits, Tokyo-Kyoto Mtg., 1970, Papers and Proc. (IAGOD volume): Soc. Mining Geologists Japan, Spec. Issue $3, p .261-267$.

Cooley, W.W., and Lohnes, P.R., 1962, Multivariate procedures for the Behavioral Sciences: John Wiley \& Sons, New York, $211 \mathrm{p}$.

Gott, G.B., Botbol, J.M., 1975, Possible extension of mineral belts, northern part of Coeur d'Alene district, Idaho: U.S. Geol. Survey Jour. Research, v. 3, no. 1, Jan.-Feb., p. 1-7. , 1973, Zoning of major and minor metals in the Coeur d'Alene district, Idaho, U.S.A.: Geochemical Exploration 1972, I.M.M., London, p. 1-12. Harrison, J.E., 1972, Precambrian Belt Basin of northwestern United States--Its geometry, sèdimentation, and copper occurrences: Geol. Soc. American Bull., v. 83, no. 5, p. $1215-1240$. 
Hobbs, W.H., Griggs, A.B., Wallace, R.E., and Campbell, A.B., 1965, Geology of the Coeur d'Alene district, Shoshone County, Idaho: U.S. Geol. Survey Prof. Paper 478, $139 \mathrm{n}$. McCammon, R.B., 1974, The statistical treatment of geochemical data: In Introduction to exploration geochemicstry by A.A. Levinson, Applied Publ., Ltd., Calgary, 612 p. 


\section{Appendix.}

Let $G$ be defined as a $n \times n$ square matrix (the product matrix of figure 3) which represents the pairwise joint occurrence of 4 variables for 5 cells in the model area of figure 2.

$$
G=\left[\begin{array}{llll}
3 & 1 & 3 & 1 \\
1 & 3 & 2 & 1 \\
3 & 2 & 4 & 1 \\
1 & 1 & 1 & 2
\end{array}\right]
$$

The object is to calculate the largest eigenvalue and determine the set of coefficients of the associated eigenvector of $\mathbf{G}$.

By deflnition, the eigenvector of a real square matrix $G$ can be expressed as

$$
\mathbf{G}=\lambda \mathbf{v}
$$

where the eigenvector is represented as a $n \times 1$ vector and $\lambda$ is the eigenvalue represented as a scalar. Solution for $v$ and $\lambda$ is by a method of iteration which is described in Cooley and Lohnes (1962).

Begin by assuming that $v_{0}=(1,1, \ldots, 1)$ is an eigenvector of $G$, and calculate

$$
v_{1}=G v_{0}
$$


If $v_{0}$ is an eigenvector of $G$, it follows that $v_{1}$ wili be a multiple of $v_{0}$, the multiplication factor being the eigenvalue $\lambda$. In general, it will not be true that vo will be an eigenvector. By successive multiplication however, a succession of vectors $v_{r}$ can be obtained defined as

$$
v_{\mathbf{x}}=G v_{x-1}
$$

where $r$ represents the number of iterations. Provided the second largest eigenvalue is not equal or close to the first, the iteration scheme above will converge to the largest eigenvector of the matrix $G$. 
In the iteration scheme, the approximation to the eigenvalue may be obtained by scaling each approximation to the eigenvector by dividing all its elements by the element which corresponds to the variable in $G$ for which

$$
B_{11}+\sum_{j \neq 1} B_{i j} . \quad 1=1, \ldots, n
$$

is a maximum and which is the approximation to the eigenvalue. In this example, this would correspond to the third variable for which the above expression has the maximum value of 10 . The iterations are performed until there is no basic change In the coefficients of the eigenvector. The change is measured as the sum of the absolute differences between the coefficients obtained for successive approximations. In the present application, when the change is less than $10^{-5}$, convergence is accepted. Usually this occurs in , less than 10 iterations of the method. 
For our example, calculating $y_{i}$ as

$\left[\begin{array}{llll}3 & 1 & 3 & 1 \\ 1 & 3 & 2 & 1 \\ 3 & 2 & 4 & 1 \\ 1 & 1 & 1 & 2\end{array}\right]\left[\begin{array}{l}1 \\ 1 \\ 1 \\ 1\end{array}\right]=\left[\begin{array}{r}8 \\ 7 \\ 10 \\ 5\end{array}\right]$

which, when scaled by diuiding each element by 10 , becomes $(.8, .7,1, .5)$. Calculating the sum of the absolute differences between the coefficients of $v_{2}$ and $v_{0}$ as

$$
\begin{gathered}
|1-.8|+|1-.7|+|1-1|+|1-.5| \\
=.2+.3+0+.5=1
\end{gathered}
$$

which is obviously far from the value selected as the test for convergence. 
Next, calculating $v_{2}$, as

$$
\left[\begin{array}{llll}
3 & 1 & 3 & 1 \\
1 & 3 & 2 & 1 \\
3 & 2 & 4 & 1 \\
1 & 1 & 1 & 2
\end{array}\right]\left[\begin{array}{c}
.8 \\
.7 \\
1 \\
.5
\end{array}\right]=\left[\begin{array}{l}
6.6 \\
5.4 \\
8.3 \\
3.5
\end{array}\right]
$$

and again, scaling $v_{2}$ by dividing by the third element, $(.795, .651,1, .422)$ is obtained. Next, the sum of the differences between $v_{1}$ and $v_{2}$ is calculated as follows:

$$
\begin{aligned}
& .8-.795+1.7-.651+1-1+.5-.422 \\
& =.005+.05+0+.078=.133
\end{aligned}
$$

This is considerably less than the first sum of the absolute differences but still greater than the test value for convergence. The iteration process is continued until convergence. Convergence in this example is achieved after the loth iteration in which the sum of the absolute differences is equal to $.3 \times 10^{-5}$ which is less than $10^{-5}$. The eigenvector after the loth iteration has as coefficients, $(.797, .632,1, .401)$. When normalized so that the sum of squares of the coefficients is equal to one, the eigenvector becomes $(.538, .427, .674, .270)$. The elgenvalue corresponding to the eigenvector is equal to 8.058 . 
ஜ

\begin{tabular}{|c|c|c|c|c|c|c|c|c|c|c|c|c|}
\hline$(L)$ & $\begin{array}{r}\qquad S \cdot L \tau \\
\text { buṭuxow IETS }\end{array}$ & $\stackrel{-1}{m}$ & m & m. & $\vec{m}$ & $\stackrel{a}{m}$ & m. & $\stackrel{n}{\sim}$ & m & $\stackrel{\Xi}{\sim}$ & $\stackrel{a}{m}$ & $\stackrel{-1}{m}$ \\
\hline$(\varepsilon \tau)$ & $\begin{array}{r}T Z \\
8 \varepsilon \cdot 0 T \\
\text { seT7甘 }\end{array}$ & 궁 & $\stackrel{-1}{*}$ & 울 & $\stackrel{\infty}{\sim}$ & n & $\stackrel{y}{y}$ & $\stackrel{+}{-1}$ & n & 웅 & 오 & 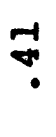 \\
\hline (s) & $\begin{array}{r}\text { TT } \\
00^{\circ} 9 \\
\text { wrozsmous }\end{array}$ & m & 옹 & 웅 & 웅 & 웅 & 웅 & 8 & กี & กี & m & $\hat{m}$ \\
\hline$(9)$ & $\begin{array}{r}00^{\circ} \varepsilon \\
\text { xpoy } \bar{\varepsilon}{ }^{8}\end{array}$ & 웅 & 웅 & $\stackrel{\infty}{n}$ & 8 & $\stackrel{\infty}{n}$ & 0 & 8 & 8 & 웅 & 8 & $\stackrel{\infty}{\infty}$ \\
\hline$(L)$ & 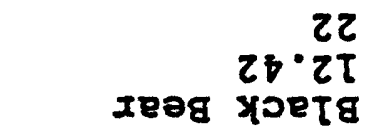 & 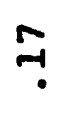 & $\ddot{n}$ & $\stackrel{a}{?}$ & $m$ & $\stackrel{1}{9}$ & $m$ & $\tilde{I}$ & 8 & $\stackrel{9}{?}$ & $\stackrel{\sim}{*}$ & in \\
\hline$(\varepsilon)$ & $\begin{array}{r}0 \cdot \varepsilon \\
\text { sətกอมวน }\end{array}$ & 용 & 웅 & 웅 & i & $\stackrel{\infty}{\infty}$ & @ & 웅 & 8 & 웅 & 응 & 웅 \\
\hline$(8)$ & $\begin{array}{r}9 Z \\
9 S^{\circ} \varepsilon \tau \\
\text { xoexeure }\end{array}$ & 울. & 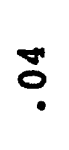 & రீ & ตํ. & m & in & $\stackrel{m}{*}$ & 울 & $\stackrel{m}{m}$ & $\stackrel{m}{0}$ & 오 \\
\hline$(b)$ & $\begin{array}{r}00^{\circ} L \\
\text { euteteg }\end{array}$ & $\stackrel{\infty}{m}$ & 웅 & $\stackrel{\infty}{m}$ & $\stackrel{\infty}{m}$ & 8 & $\stackrel{\infty}{m}$ & $\stackrel{\infty}{m}$ & 8 & 웅 & $\stackrel{\infty}{m}$ & $\stackrel{\infty}{m}$ \\
\hline$(O T)$ & $\begin{array}{r}S T \\
9 L \cdot S \\
\text { eTDeH }\end{array}$ & $\stackrel{\infty}{*}$ & 옹 & 웅 & $\stackrel{\infty}{m}$ & 욱. & $\stackrel{\infty}{m}$ & -1 & $\stackrel{6}{*}$ & $\stackrel{\infty}{-1}$ & $\stackrel{9}{*}$ & \% \\
\hline$(Z T)$ & $\begin{array}{r}95^{\circ} 8 \\
\text { TTFH xөxung }\end{array}$ & $\stackrel{m}{m}$ & 웅 & $\stackrel{0}{0}$ & $\tilde{m}$ & $\ddot{m}$ & $\stackrel{m}{m}$ & $m$ & $\stackrel{n}{*}$ & 욱. & $\stackrel{m}{m}$ & $m$ \\
\hline$(9)$ & $\begin{array}{r}\text { LS } \\
\text { 7Țunums } x \partial \Lambda T T S\end{array}$ & m & 웅 & m & m & m & m. & $\stackrel{m}{m}$ & 웅 & 웅 & $\stackrel{9}{-}$ & m \\
\hline$(8)$ & $\begin{array}{r}\tau Z \\
\varepsilon L \cdot Z T \\
\text { ouțบsuns }\end{array}$ & $\stackrel{⿱ 乛}{N}$ & $\stackrel{n}{n}$ & $\tilde{m}$ & $\stackrel{N}{N}$ & $\hat{m}$ & $\stackrel{n}{n}$ & $\stackrel{N}{N}$ & $\begin{array}{l}0 \\
\mathbf{N}\end{array}$ & $\stackrel{+}{\sim}$ & 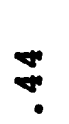 & $\underset{*}{*}$ \\
\hline$(\varepsilon \sigma)$ & 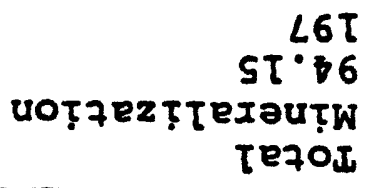 & $m$ & $\stackrel{\sim}{-}$ & 음 & $\stackrel{0}{m}$ & 울 & $\stackrel{m}{m}$ & $\stackrel{a}{v}$ & $\stackrel{9}{-1}$ & â & $\stackrel{0}{m}$ & $\stackrel{0}{*}$ \\
\hline
\end{tabular}



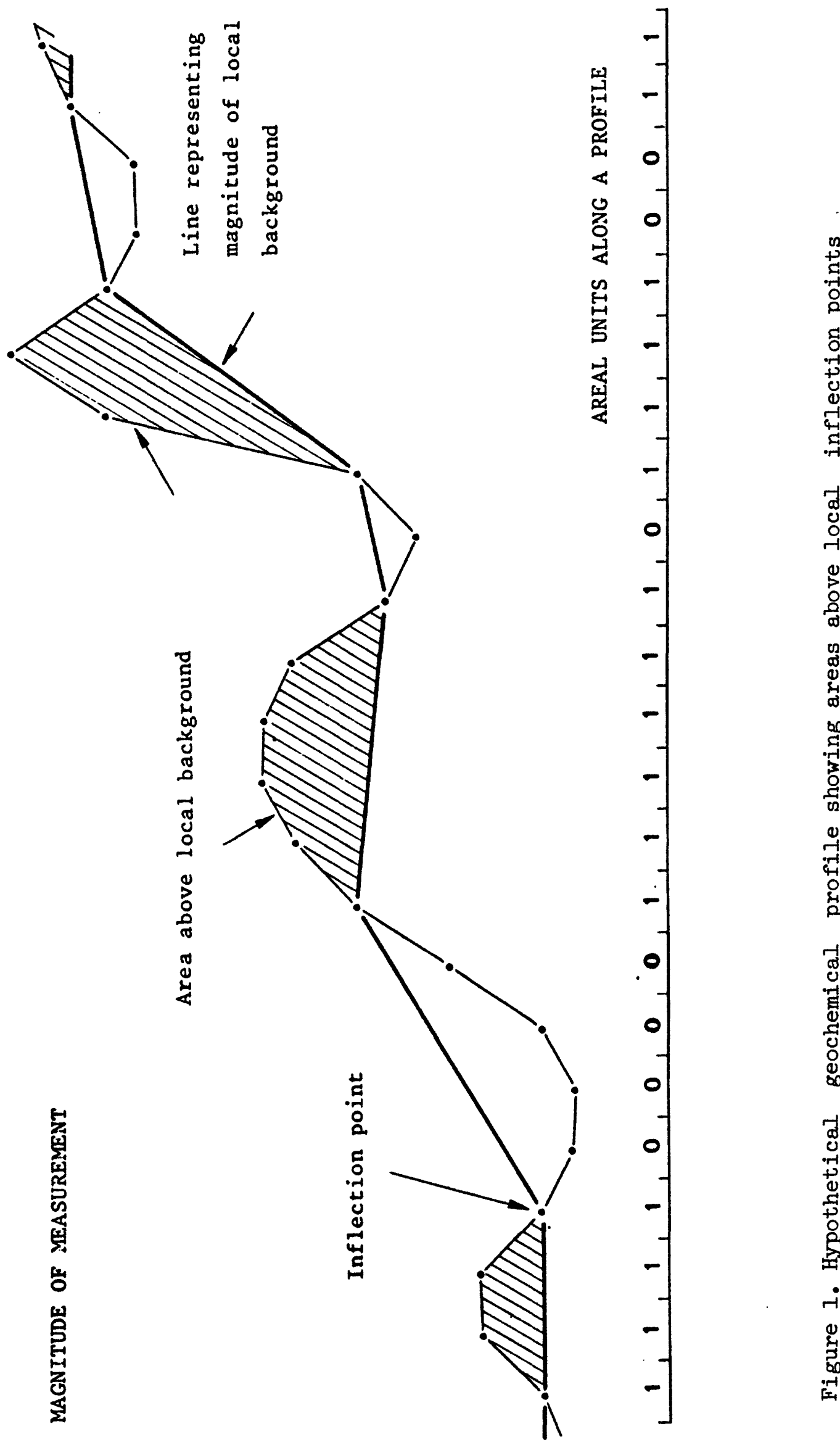

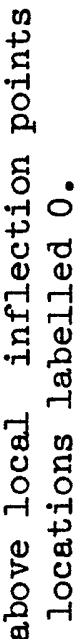

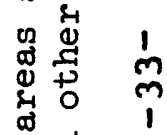

क त्ठ

क

क्ष

-
-
-
0
0

0

0

$-$

$-$

क्न

م

거워

댈

ษั

8

न1

ن d

岂

苍

空

굴

$-$ 
Cells

\begin{tabular}{|c|c|c|c|c|c|}
\hline \multirow{3}{*}{ 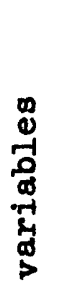 } & 1 & 2 & 3 & 4 & 5 \\
\hline & 1 & 0 & 1 & 1 & 0 \\
\hline & 0 & 1 & 0 & 1 & 1 \\
\hline$\stackrel{\Phi}{>} 3$ & 1 & 0 & 1 & 1 & 1 \\
\hline 4 & 1 & 1 & 0 & 0 & 0 \\
\hline
\end{tabular}

Figure 2. Model of four variables for five cells. 


\section{Original binary array}

$$
\begin{array}{lllll}
1 & 0 & 1 & 1 & 0 \\
0 & 1 & 0 & 1 & 1 \\
1 & 0 & 1 & 1 & 1 \\
1 & 1 & 0 & 0 & 0
\end{array}
$$

Comparison of row 1 of original binary array with itself and all other rows.

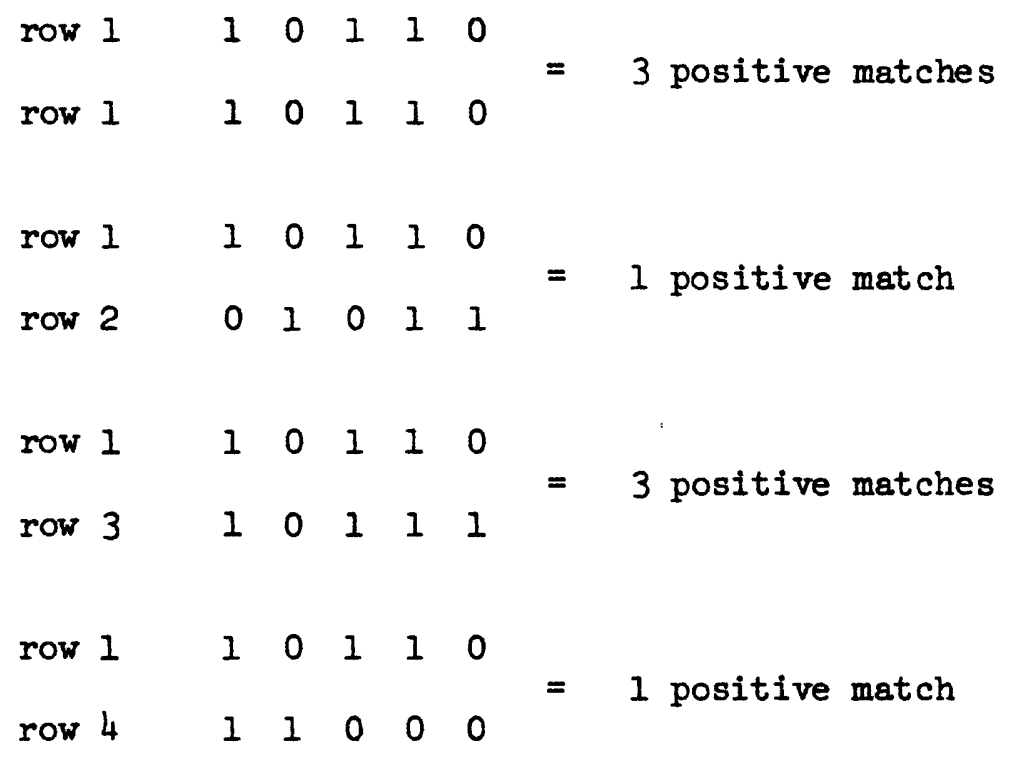

Product matrix

$$
\left|\begin{array}{lllll}
1 & 0 & 1 & 1 & 0 \\
0 & 1 & 0 & 1 & 1 \\
1 & 0 & 1 & 1 & 1 \\
1 & 1 & 0 & 0 & 0
\end{array}\right| \times\left|\begin{array}{llll}
1 & 0 & 1 & 1 \\
0 & 1 & 0 & 1 \\
1 & 0 & 1 & 0 \\
1 & 1 & 1 & 0 \\
0 & 1 & 1 & 0
\end{array}\right|=\left|\begin{array}{llll}
3 & 1 & 3 & 1 \\
1 & 3 & 2 & 1 \\
3 & 2 & 4 & 1 \\
1 & 1 & 1 & 2
\end{array}\right|
$$

Figure 3. Sample calculation of product matrix for binary array in Figure 2. 
Region Cell

variable

cell value

\begin{tabular}{|l|l|l|l|}
\hline 1 & 2 & 3 & 4 \\
\hline 1 & 1 & 1 & 0 \\
\hline
\end{tabular}

Model weights

variable

\begin{tabular}{|c|c|c|c|}
\hline 1 & 2 & 3 & 4 \\
\hline .538 & .427 & .674 & .270 \\
\hline
\end{tabular}

degree of association $=1 \times .583+1 \times .427+1 \times .674+0 \times .270=1.639$

Figure 4. Degree of association between region cell and model 


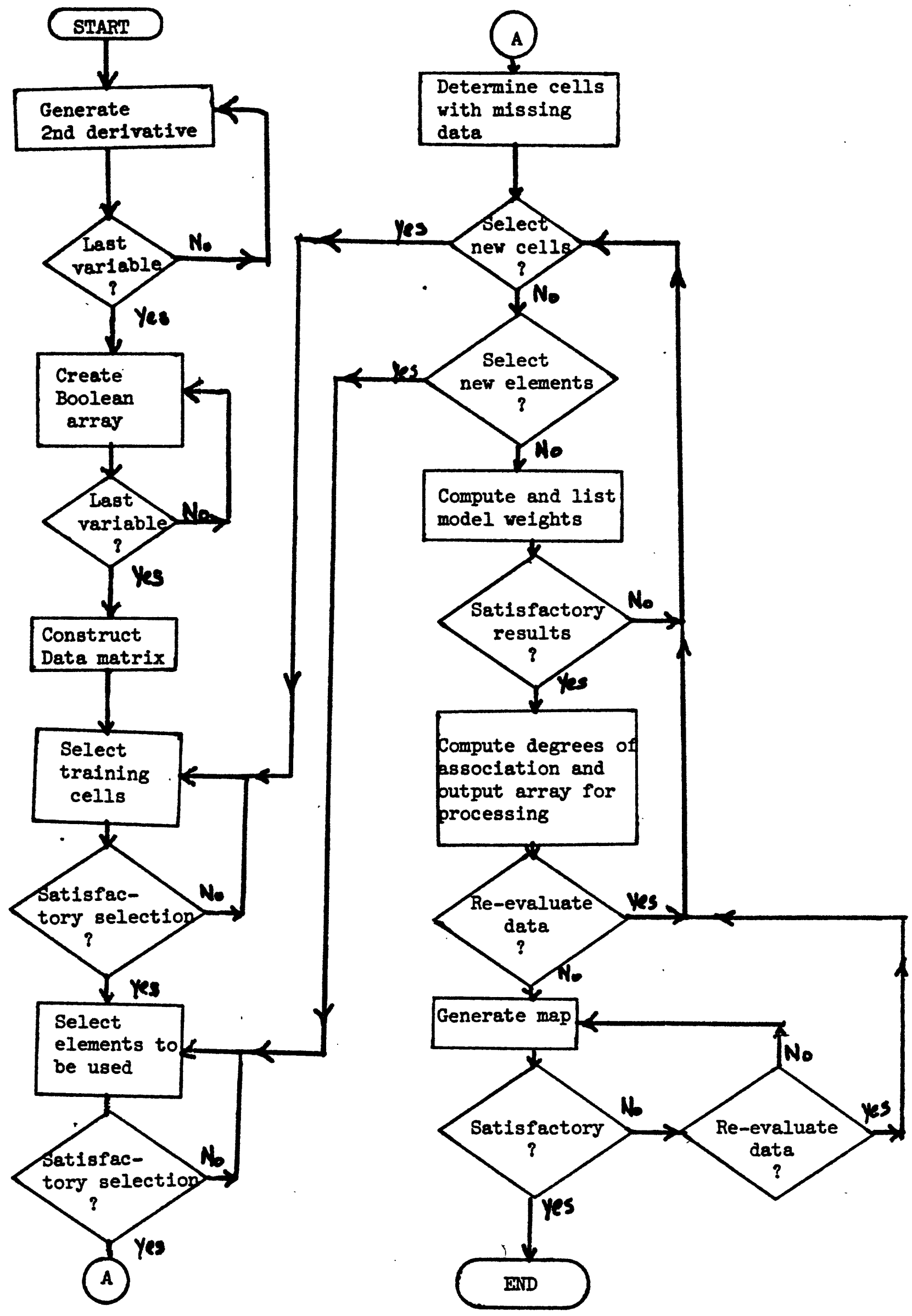

Figure 5.-Flowchart of interactive characteristic analytic technique. 


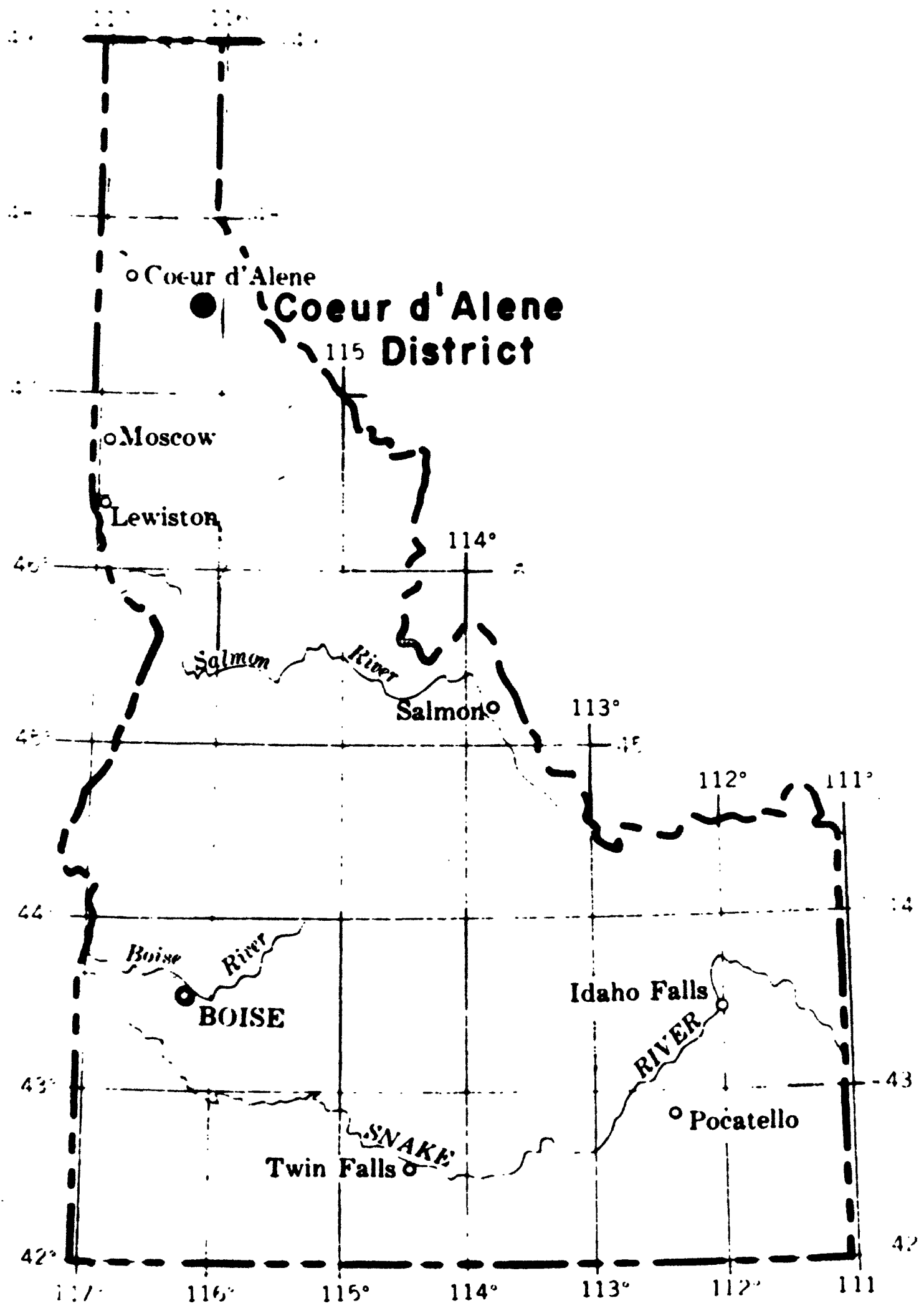

Figure 6. Index map of Idaho showing location of the Coeur d'Alene mining district. 


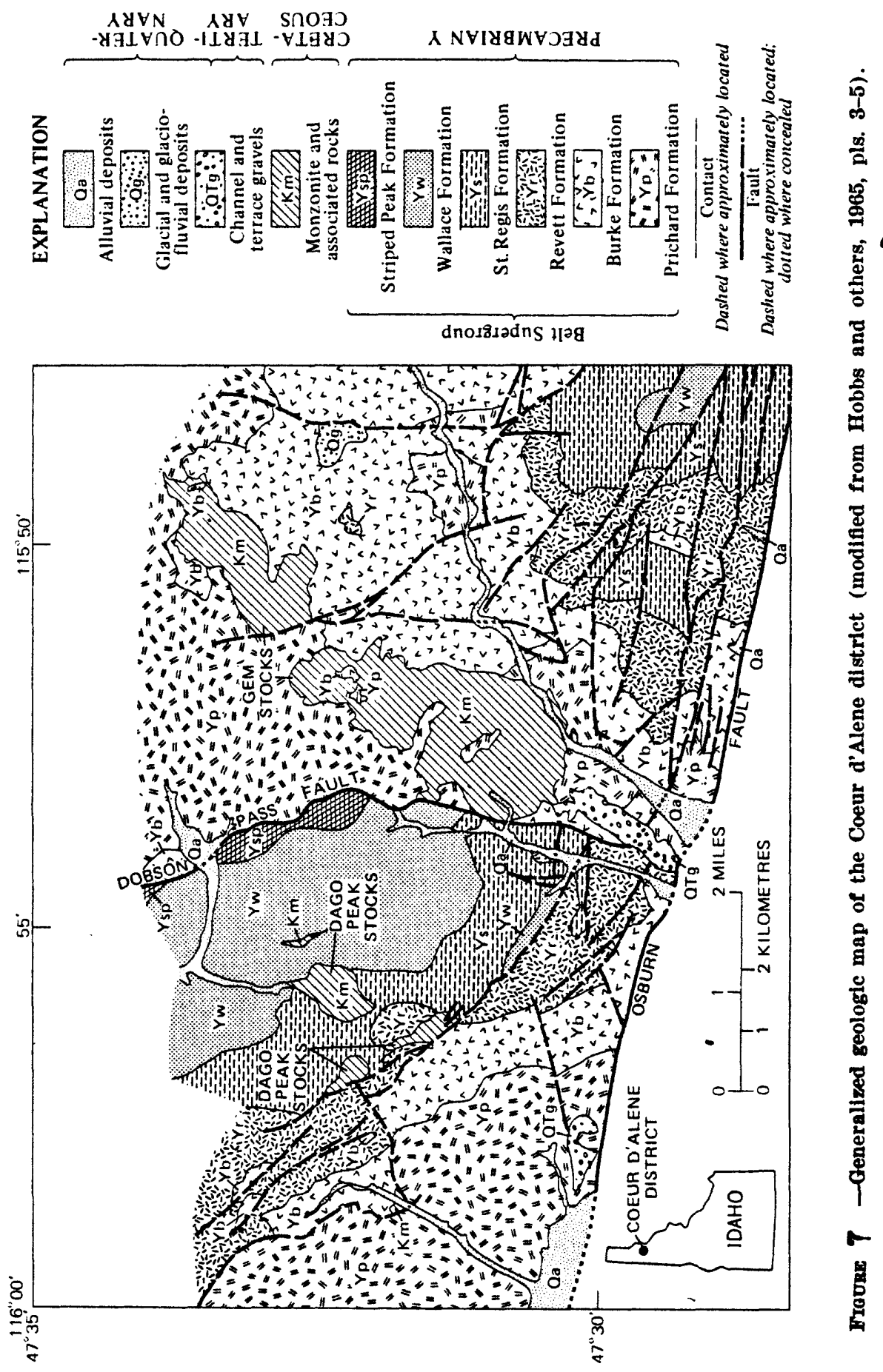

กิ 

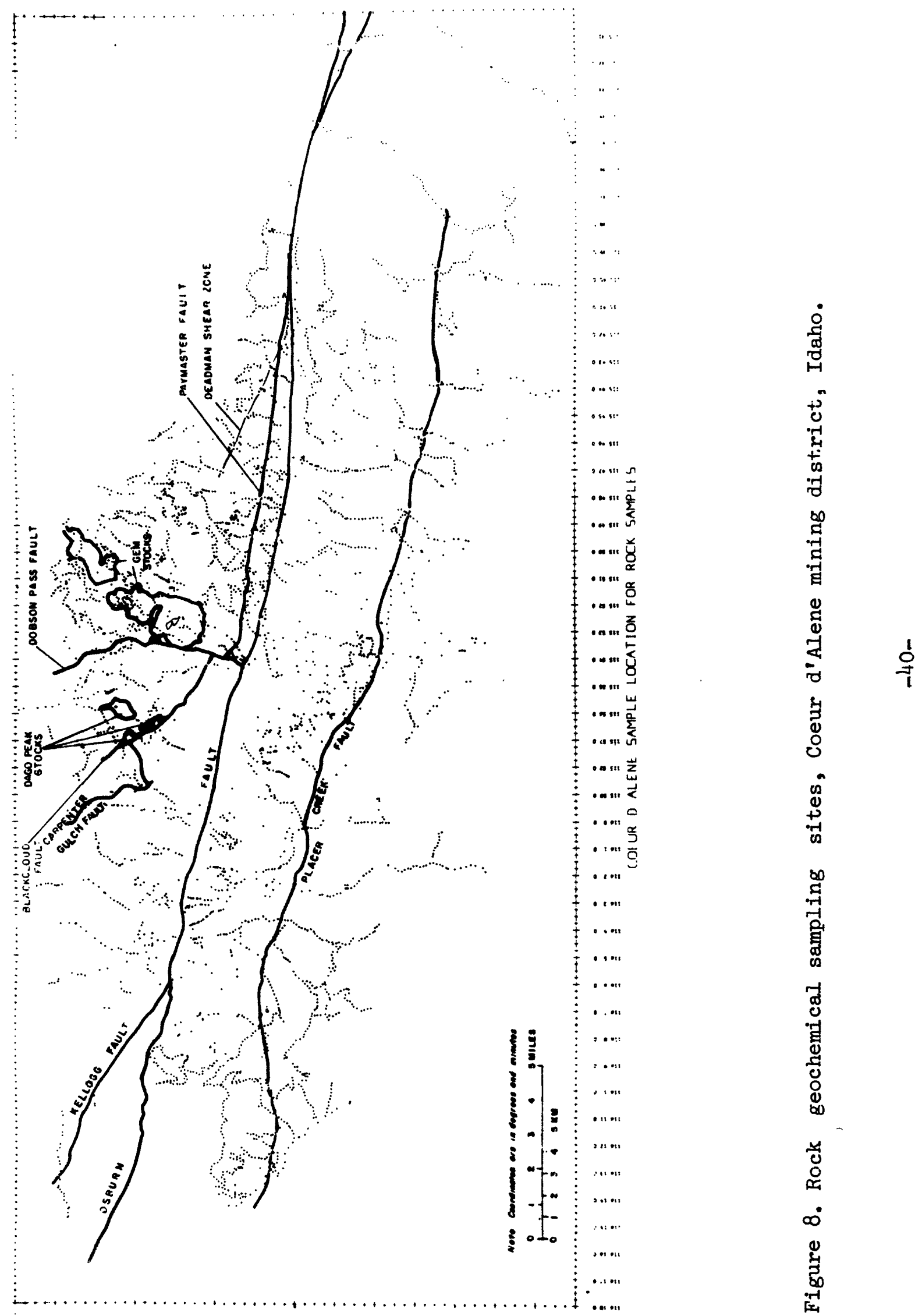

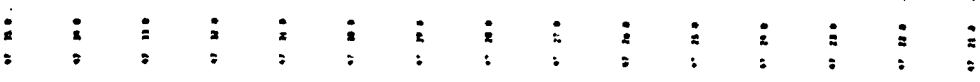




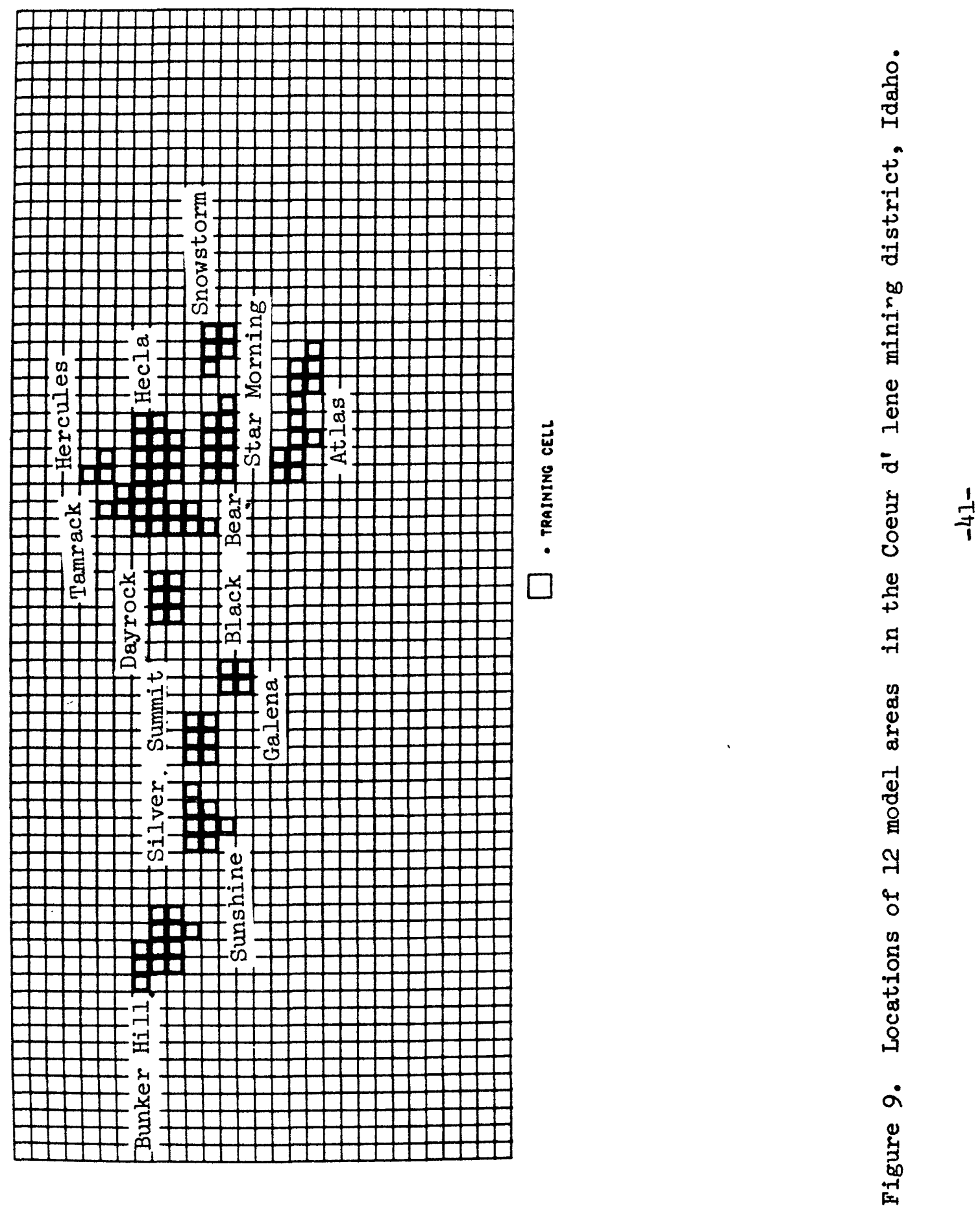


F1gure 10. Degrees of association of the Coeur d' Alene mining district with the Atlas model area.

a. Plan map showing distribution of degrees of association of the entire district with the model area. Model cells are doubly outlined. Solid cells are non-aggregate model anomalies.

b. Perspective drawing of ' $a$ ' (above) showing only highest levels of association.

c. Frequency distribution of contour levels (exclusive of model). Level Explanation

1 Low degree of association between cell and model.

2 Low-moderate degree of association between cell and model.

3 Moderate-high degree of assoclation between cell and model.

4 High degree of association between cell and model.

blank Ho data. 

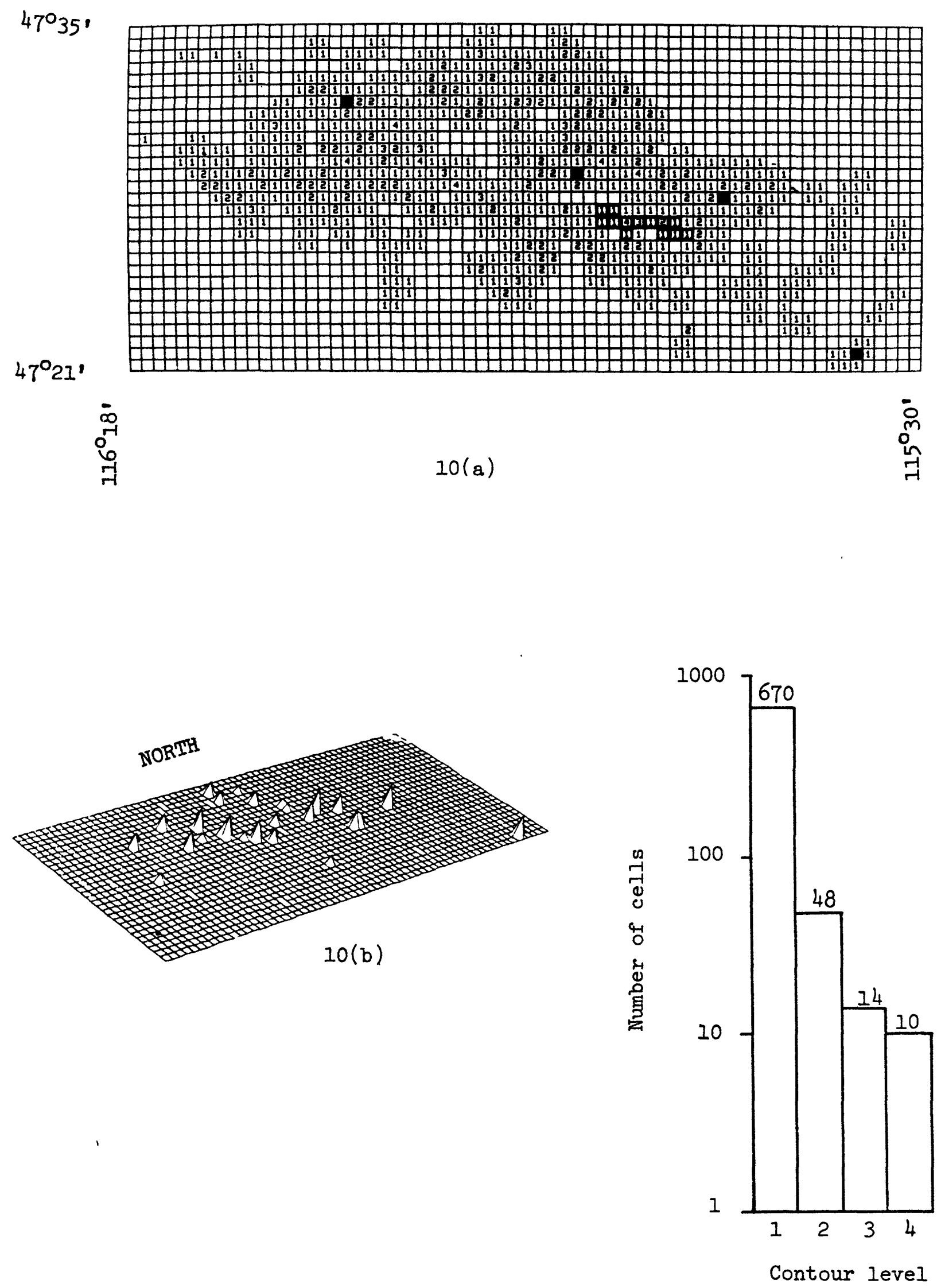
Figure 11. Degrees of association of the Coeur d' Alene mining district with the Black Bear model area.

a. Plan map showing distribution of degrees of association of the entire district with the model area. Model cells are doubly outlined. Solid cells are non-aggregate model anomalies.

b. Perspective drawing of ' $a$ ' (above) showing only highest levels of association.

c. Frequency distribution of contour levels (exclusive of model). Ievel Explanation

1 Low degree of assoclation between cell and model.

2 Low-moderate degree of association between cell and model.

3 Moderate-high degree of assoclation between cell and model.

4 High degree of assoclation between cell and model. blank to data. 


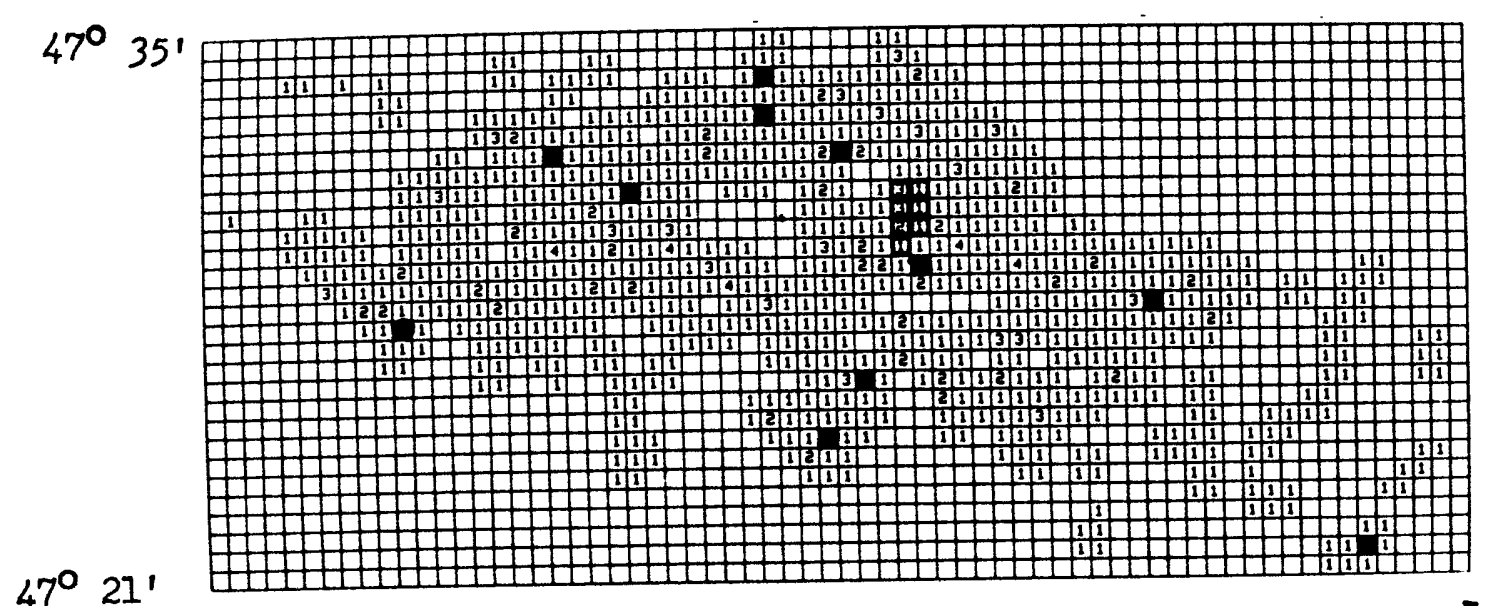

$47^{\circ} 21^{\prime}$

ì

$11(a)$
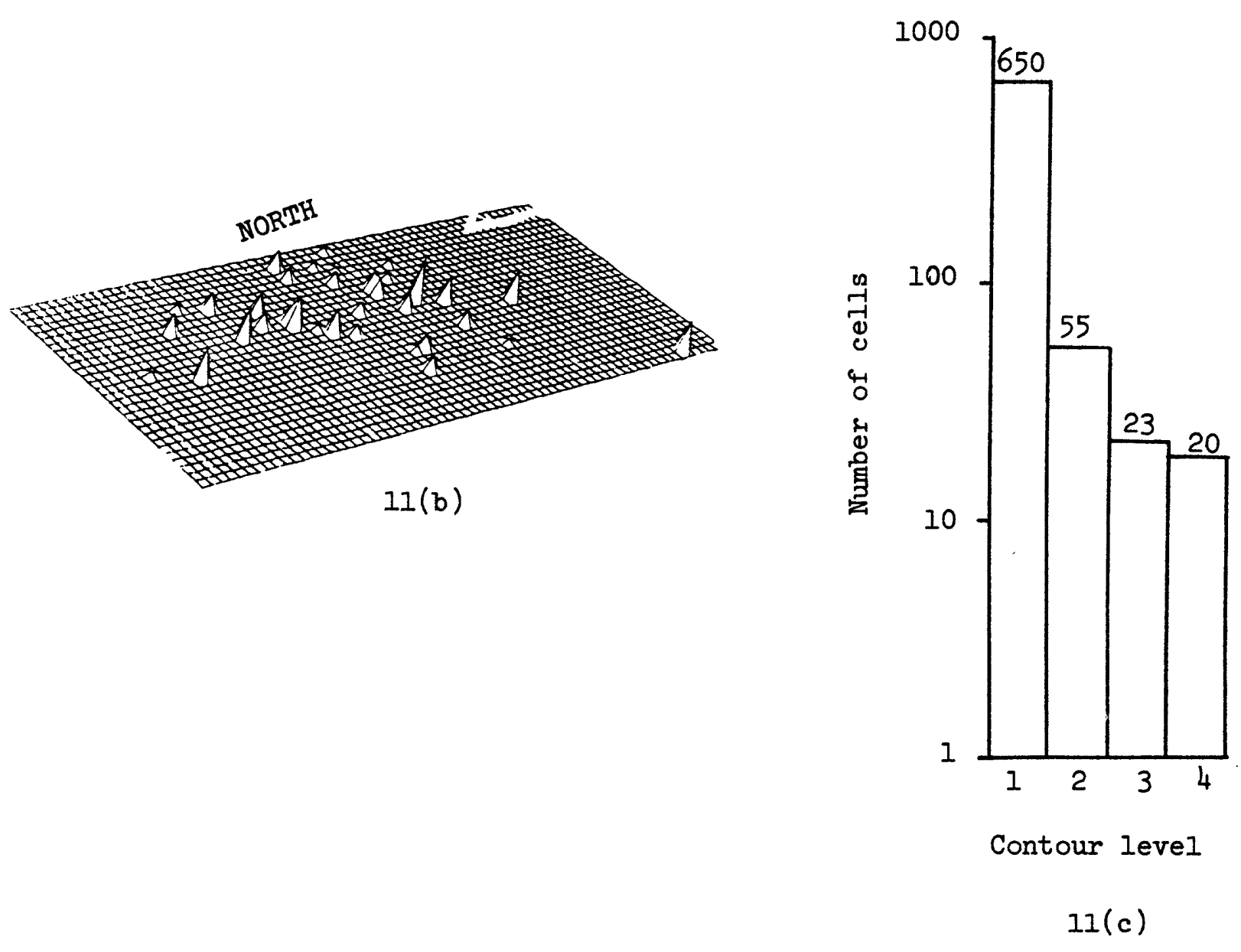
Figure 12. Degrees of assoclation of the Coeur d' Alene mining

distrlet with the Bunker H11I model area.

a. Plan map showing distribution of degrees of association of the entire district with the model area. Model cells are doubly outlined. Solid cells are non-aggregate model anomalies.

b. Perspectlve drawing of ' $a$ ' (above) showing only highest levels of assoclation.

c. Frequency distribution of contour levels (exclusive of model). Ievel Bxplanation

1 Low degree of association between cell and model. 2 Iow-moderate degree of association between cell and model. 3 Moderate-high degree of association between cell and model. 4 High degree of association between cell and model. blank No data. 

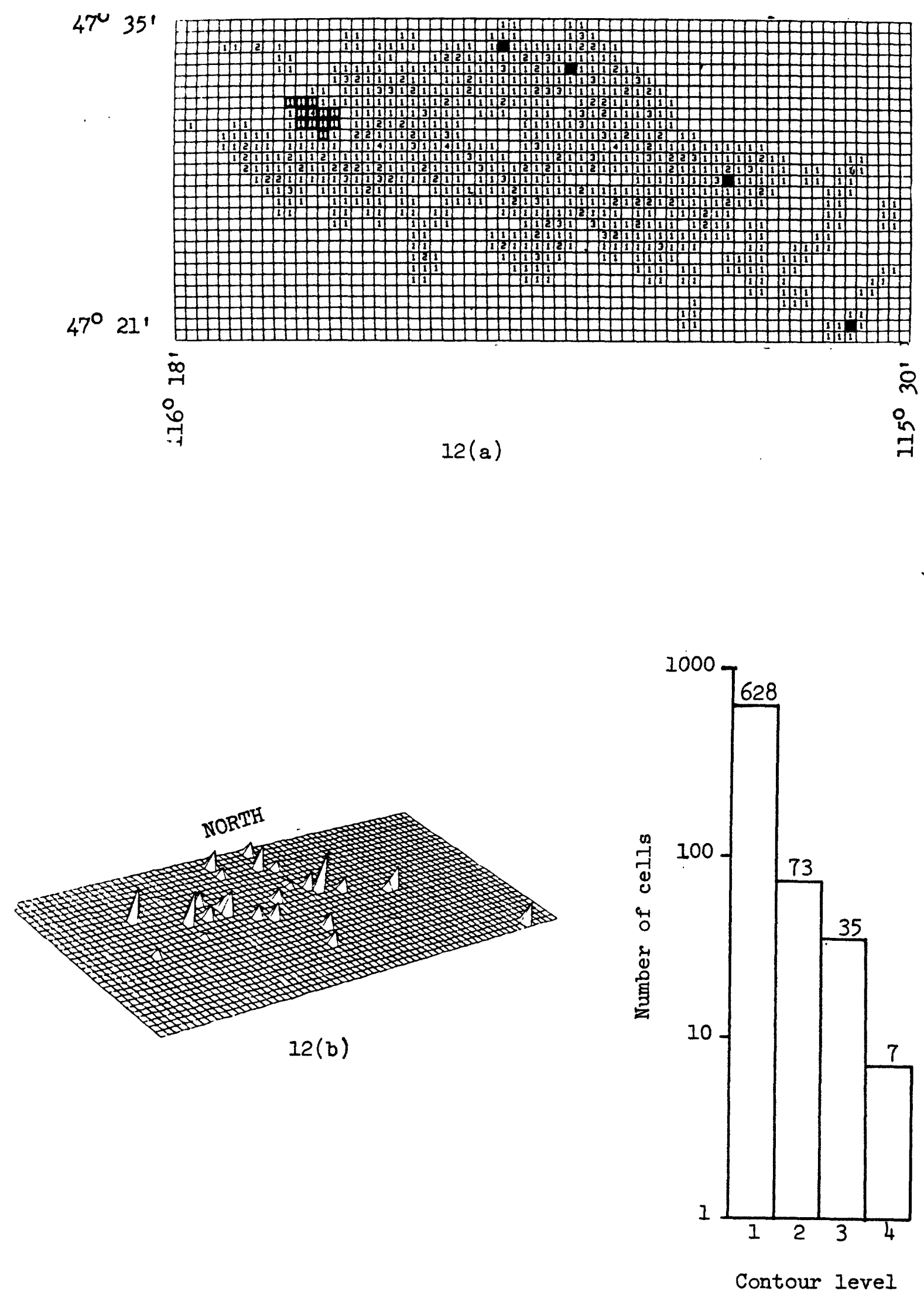

$12(c)$ 
Figure 13. Degrees of association of the Coeur d' Alene mining

district with the Day Rock model area.

a. Plan map showing distribution of degrees of association of the entire district with the model area. Model cells are doubly outllned. Solid cells are non-aggregate model anomalies.

b. Perspective drawing of ' $a$ ' (above) showing only highest levels of association.

c. Frequency distribution of contour levels (exclusive of model).

Ievel Explanation

1 Low degree of association between cell and model.

2 Low-moderate degree of association between cell and model.

3 Moderate-high degree of assoclation between cell and model.

4 High degree of association between cell and model.

blank No data. 

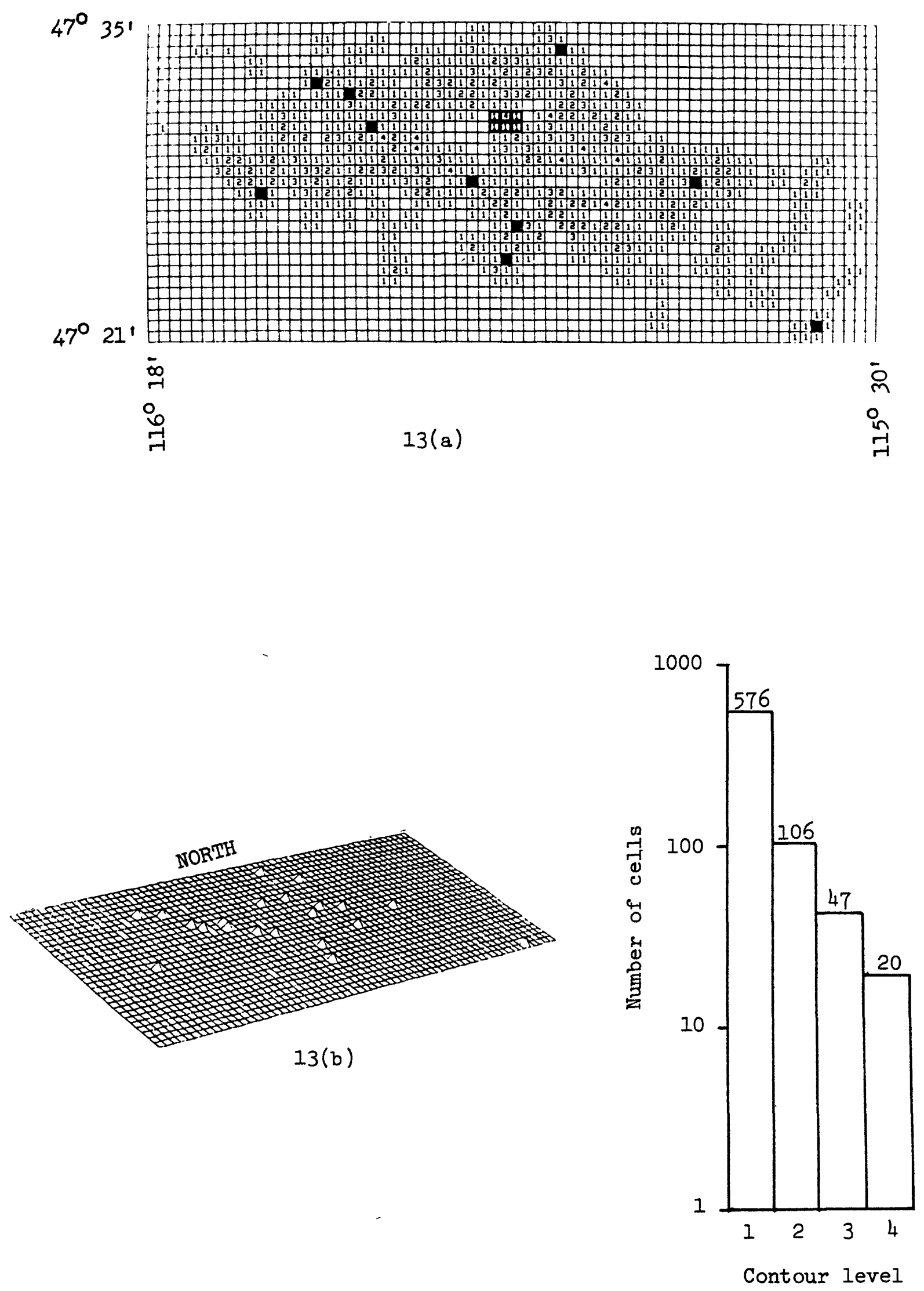
Figure 14. Degrees of association of the Coeur d' Alene mining district with the Galene model area.

a. Plan map showing distribution of degrees of association of the entire district with the model area. Model cells are doubly outlined. Solid cells are non-aggregate model anomalies.

b. Perspective drawing of ' $a$ ' (above) showing only highest levels of association.

c. Frequency distribution of contour levels (exclusive of model). Level Bxplanation

1 Low degree of association between cell and model.

2 Low-moderate degree of association between cell and model.

3 Moderate-high degree of association between cell and model.

4 High degree of association between cell and model.

blank No data. 

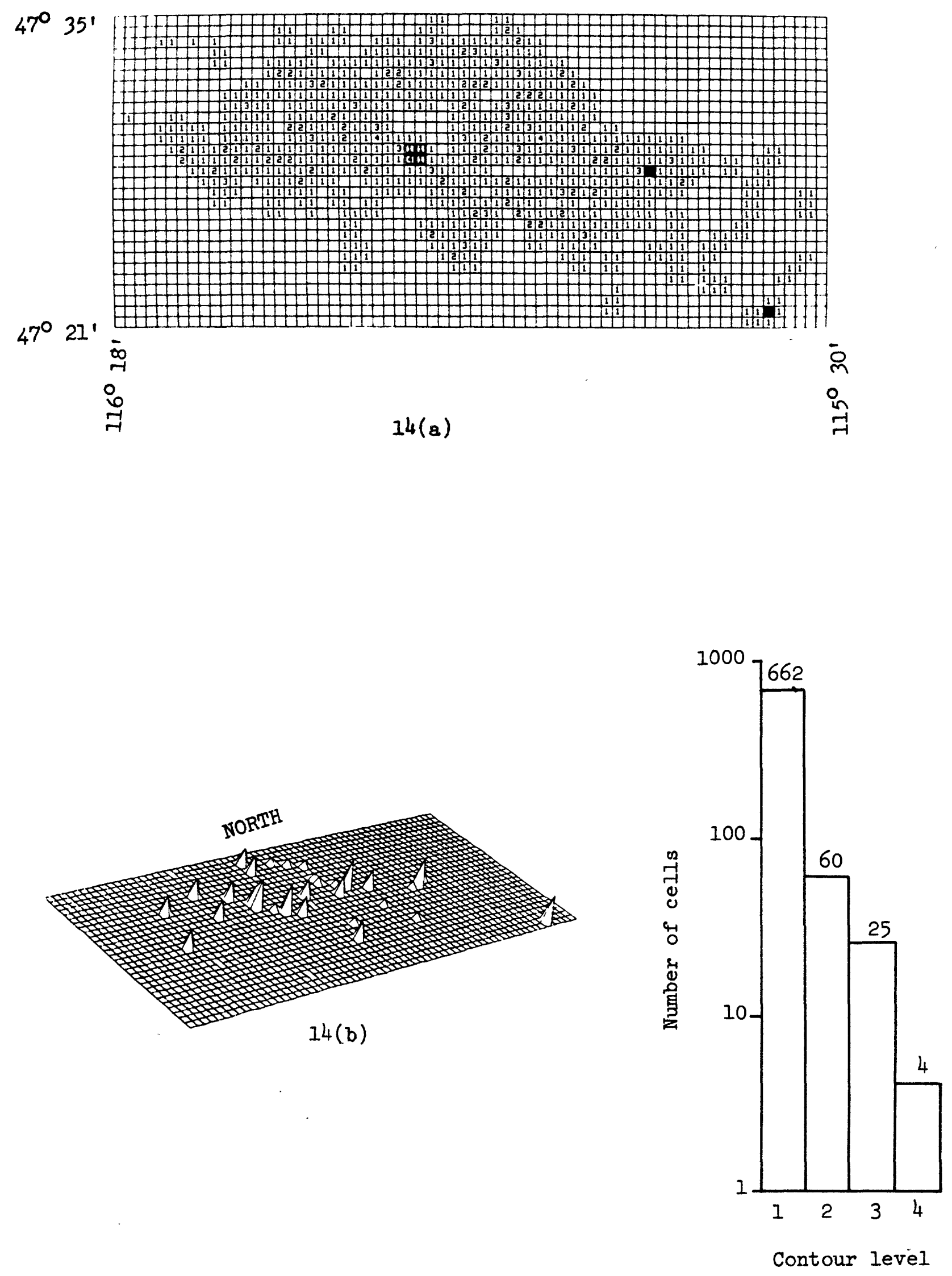

$46 a$ 
Flgure 15. Degrees of assoclation of the Coeur d' Alene mining district with the Hecla model area.

a. Plan map showing distribution of degrees of association of the entire district with the model area. Model cells are doubly outlined. Solid cells are non-aggregate model anomalies.

b. Perspective drawing of ' $\mathrm{a}$ ' (above) showing only highest levels of association.

c. Frequency distribution of contour levels (exclusive of model). Level Explanation

1 Low degree of association between cell and model.

2 Low-moderate degree of association between cell and model. 3 Moderate-high degree of association between cell and model.

4 High degree of association between cell and model. blank No data. 

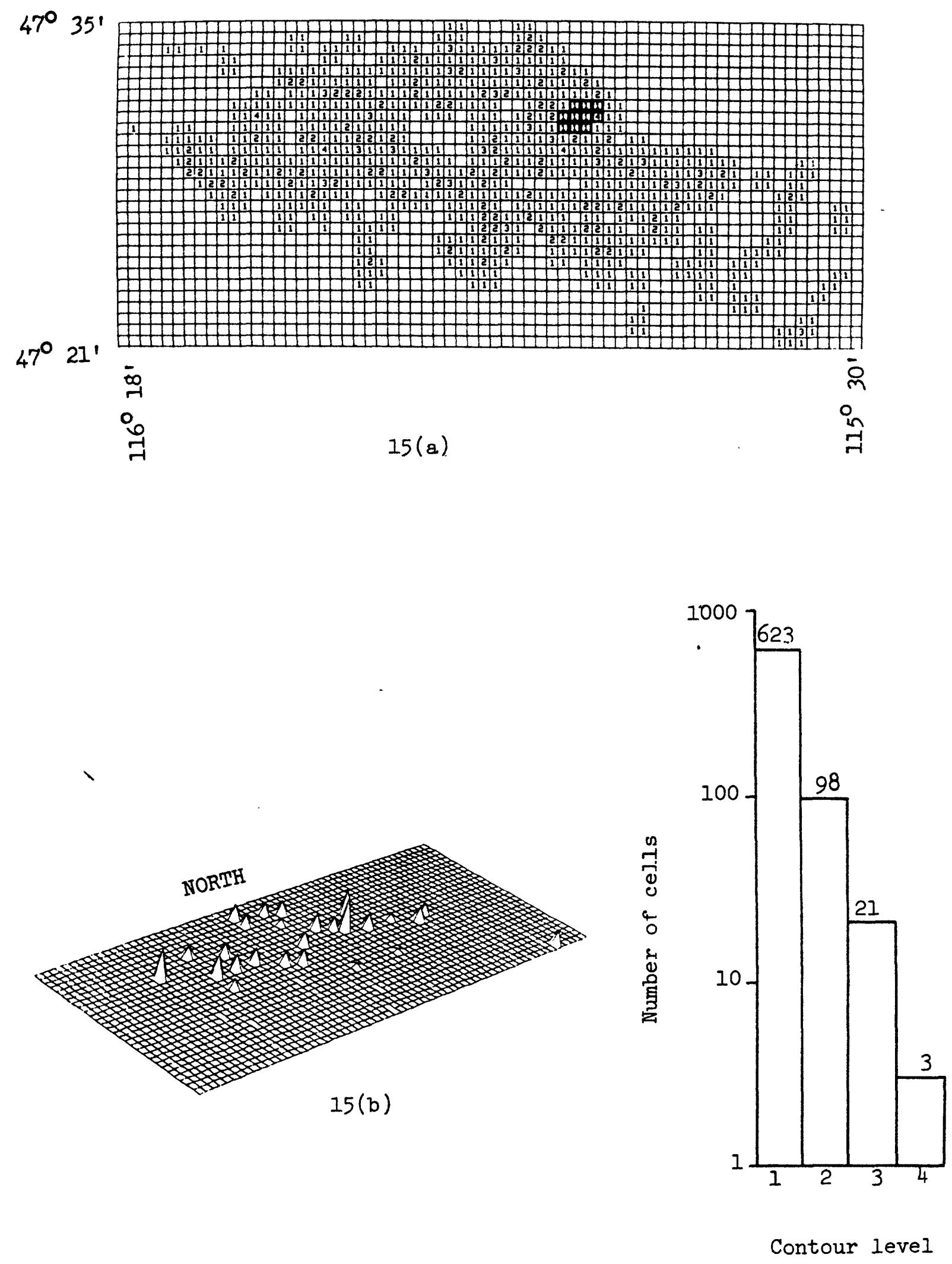

15(c) 
Flgure 16. Degrees of assoclation of the Coeur a' Alene mining district with the Hercules model area.

a. Plan map showing distribution of degrees of association of the entire district with the model area. Model cells are doubly outlined. Solid cells are non-aggregate model anomalies.

b. Perspective drawing of ' $a$ ' (above) showing only highest levels of association.

c. Frequency distribution of contour levels (exclusive of model). Level Explanation

1 Iow degree of association between cell and model. 2 Low-moderate degree of association between cell and model. 3 Moderate-high degree of association between cell and model. 4 High degree of association between cell and model. blank No data. 


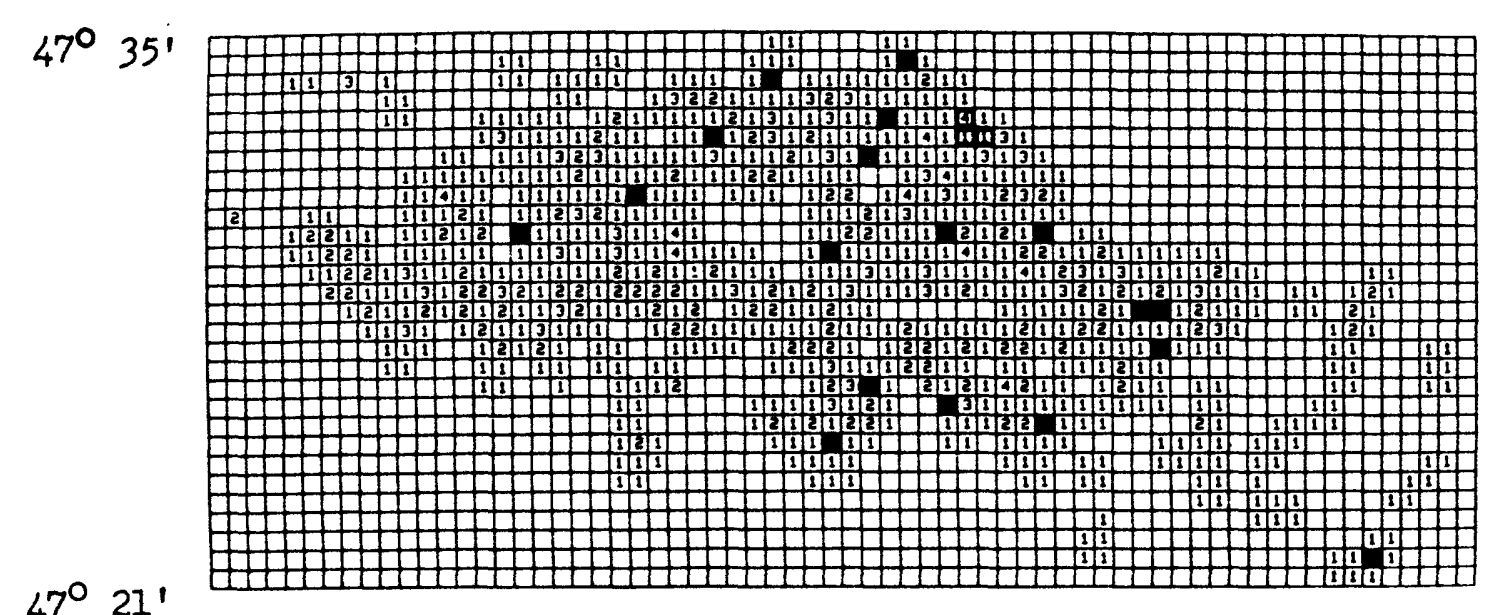

$47^{\circ} 21^{\prime}$
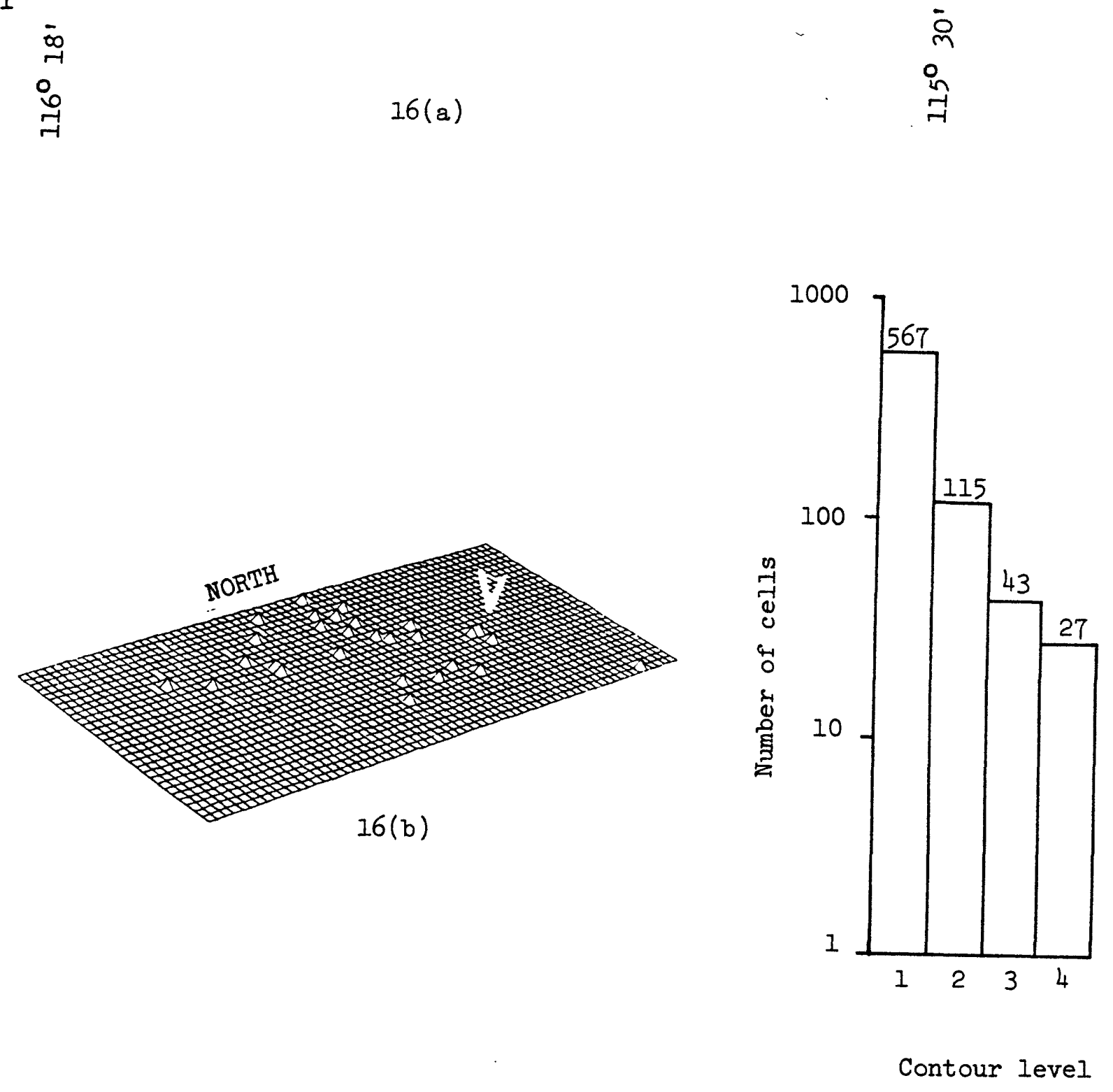

$16(c)$ 
Figure 17. Degrees of association of the Coeur a' Alene mining district with the Silver Sumit model area.

a. Plan map showing distribution of degrees of association of the entire district with the model area. Model cells are doubly outlined. Solid cells are non-aggregate model anomalies.

b. Perspective drawing of ' $a$ ' (above) showing only highest levels of association.

c. Frequency distribution of contour levels (exclusive of model). Ievel Explanation

1 Iow degree of association between cell and model.

2 Iow-moderate degree of association between cell and model.

3 Moderate-high degree of association between cell and model.

4 High degree of association between cell and model.

blank No data. 

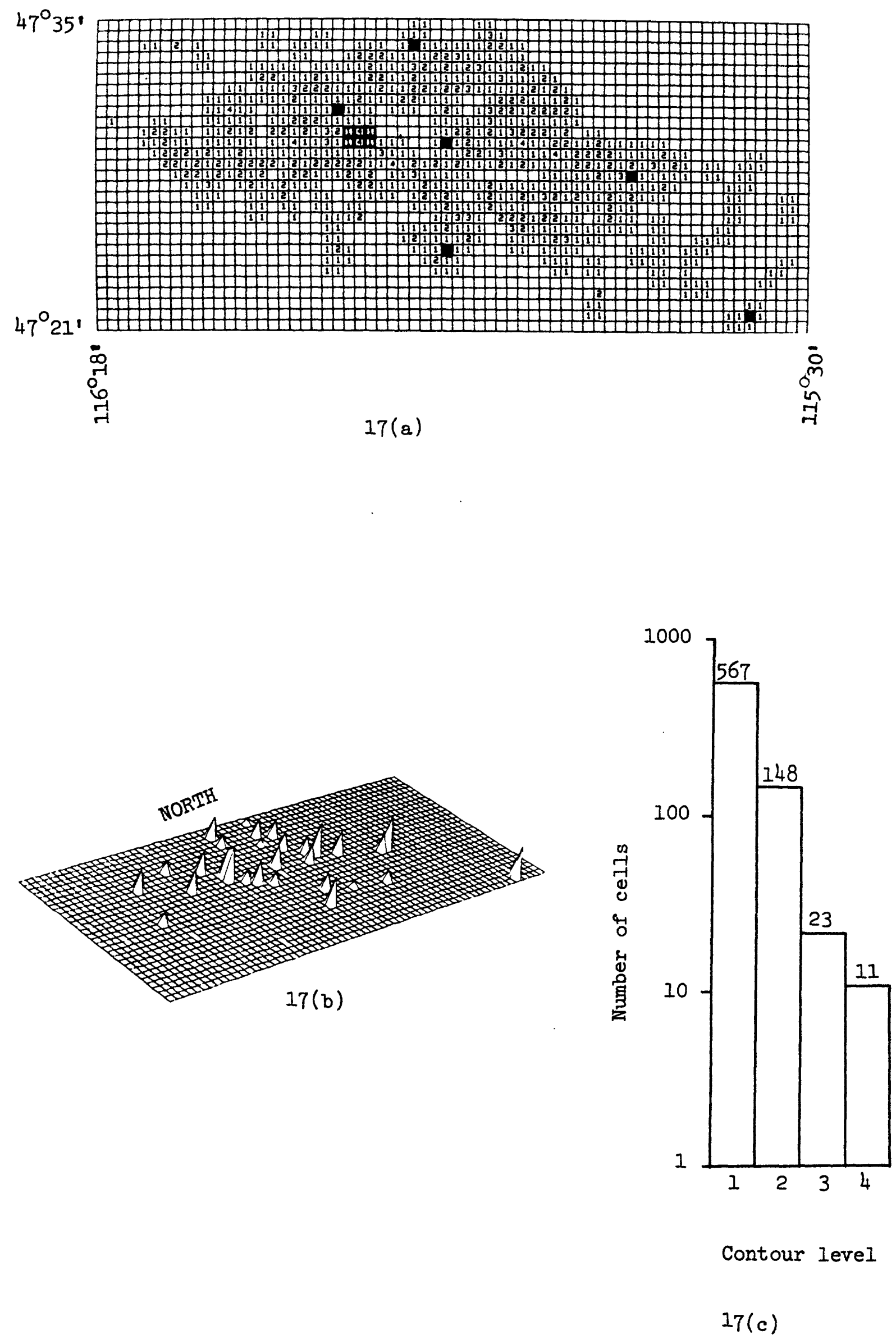

$49 a$ 
Figure 18. Degrees of assoclation of the Coeur i' Alene mining

district with the Sunshine model area.

a. Plan map showing distribution of degrees of association of the entire district with the model area. Model cells are doubly outlined. Solid cells are non-aggregate model anomalies.

b. Perspective drawing of ' $a$ ' (above) showing only highest levels of association.

c. Frequency distribution of contour levels (exclusive of model). Level Bxplanation

1 Low degree of assoclation between cell and model.

2 Low-moderate degree of association between cell and model.

3 Moderate-high degree of association between cell and model.

4 High degree of association between cell and model. blank No data.

$-50-$



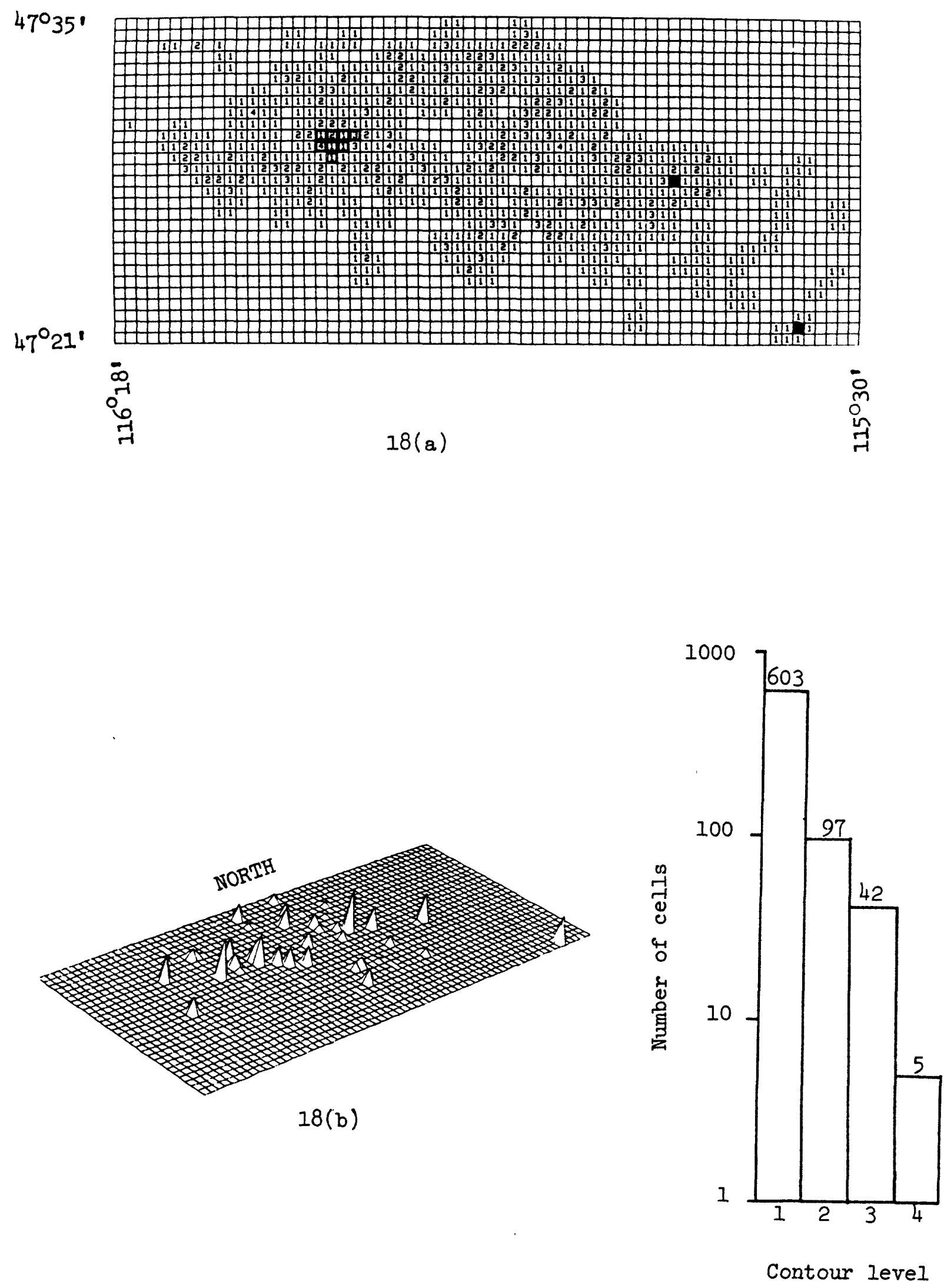

18(c) 
Figure 19. Degrees of association of the Coeur a' Alene mining district with the Snowstorm model area.

a. Plan map sbowing distribution of degrees of association of the entire district with the model area. Model cells are doubly outlined. Solid cells are non-aggregate model anomalies.

b. Perspective drawing of ' $a$ ' (above) showing only highest levels of association.

c. Frequency distribution of contour levels (exclusive of model). Ievel Explanation

1 Low degree of association between cell and model.

2 Low-moderate degree of association between cell and model.

3 Moderate-high degree of association between cell and model.

4 High degree of association between cell and model.

blank No data. 

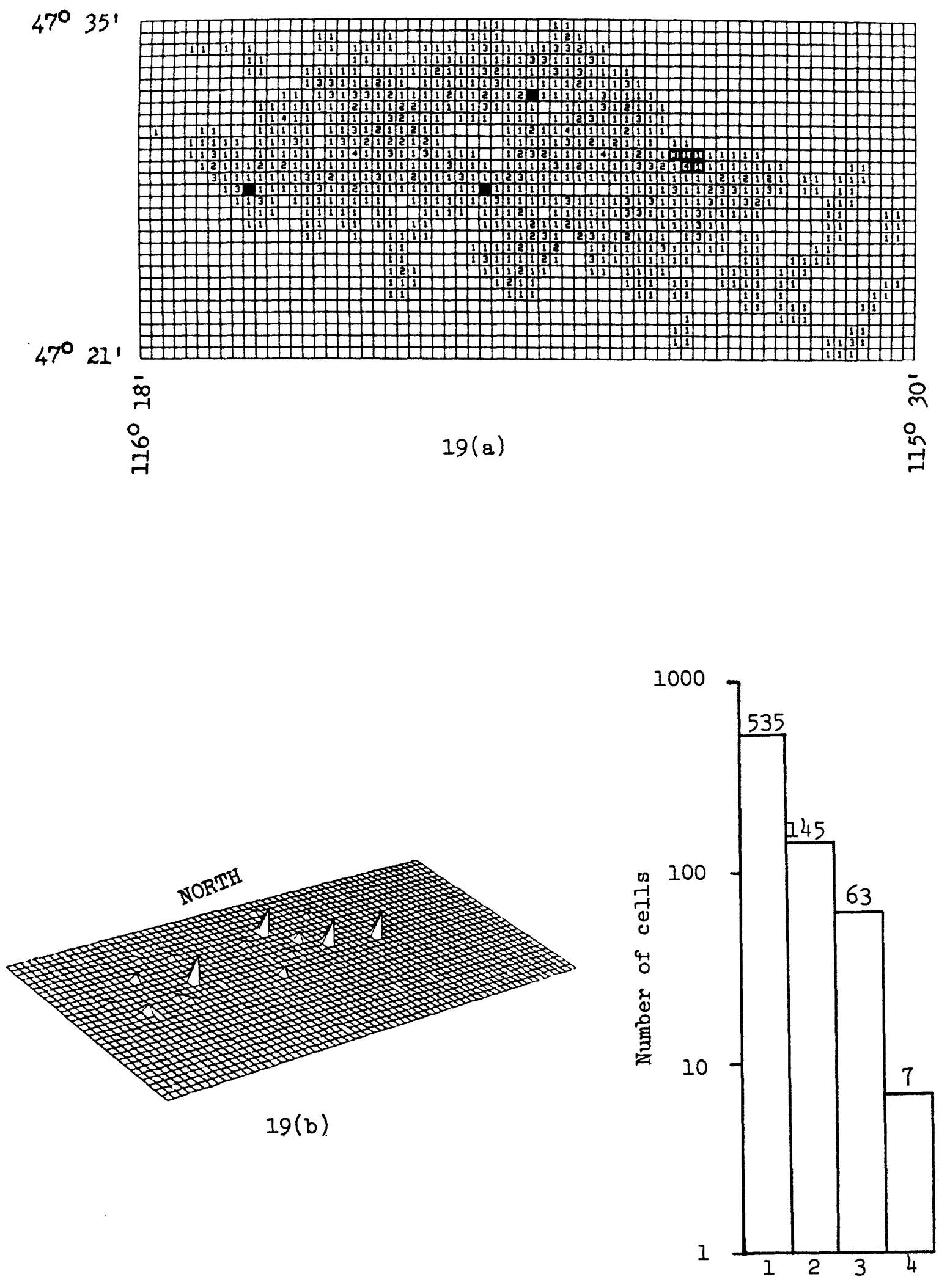

Contour level 
Figure 20. Degrees of association of the Coeur a' Alene mining district with the Star Morning model area.

a. Plan map showing distribution of degrees of association of the entire district with the model area. Model cells are doubly outlined. Solid cells are non-aggregate model anomalies.

b. Perspective drawing of ' $a$ ' (above) showing only highest levels of association.

c. Frequency distribution of contour levels (exclusive of model). Ievel Explanation

1 Low degree of association between cell and model.

2 Low-moderate degree of association between cell and model.

3 Moderate-high degree of association between cell and model.

4 High degree of association between cell and model.

blank To data. 

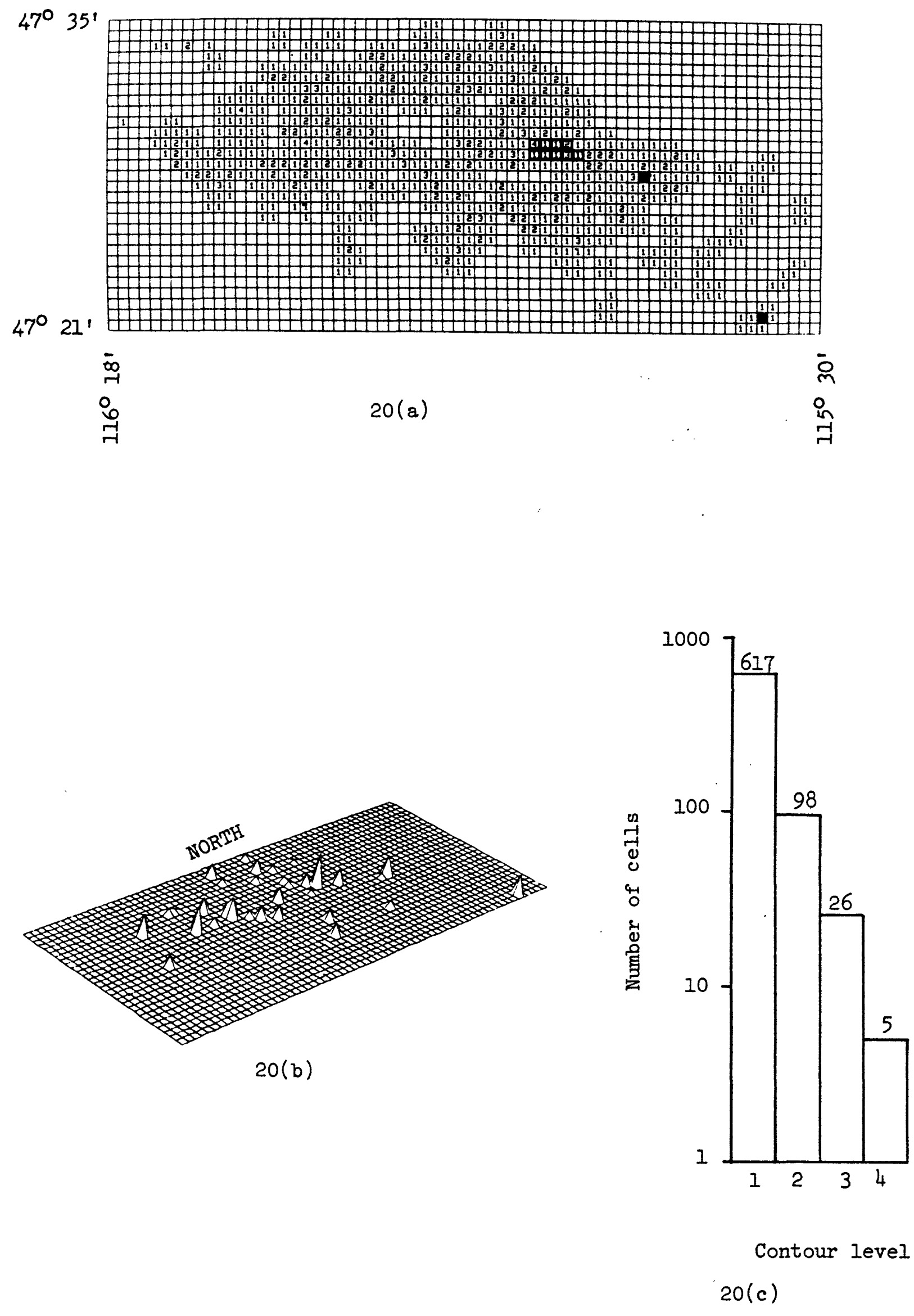

$52 a$ 
Figure 21. Degrees of association of the Coeur a' Alene mining

district with the Tamarack model area.

a. PIan map showing distribution of degrees of assoclation of the entire district with the model area. Model cells are doubly outlined. Solid cells are non-aggregate model anomalies.

b. Perspective drawing of ' $a$ ' (above) showing only highest levels of association.

c. Frequency distribution of contour levels (exclusive of model). Level Explanation

1 Low degree of association between cell and model.

2 Iow-moderate degree of assoclation between cell and model.

3 Moderate-high degree of association between cell and model.

4 HIgh degree of association between cell and model. blank No date. 

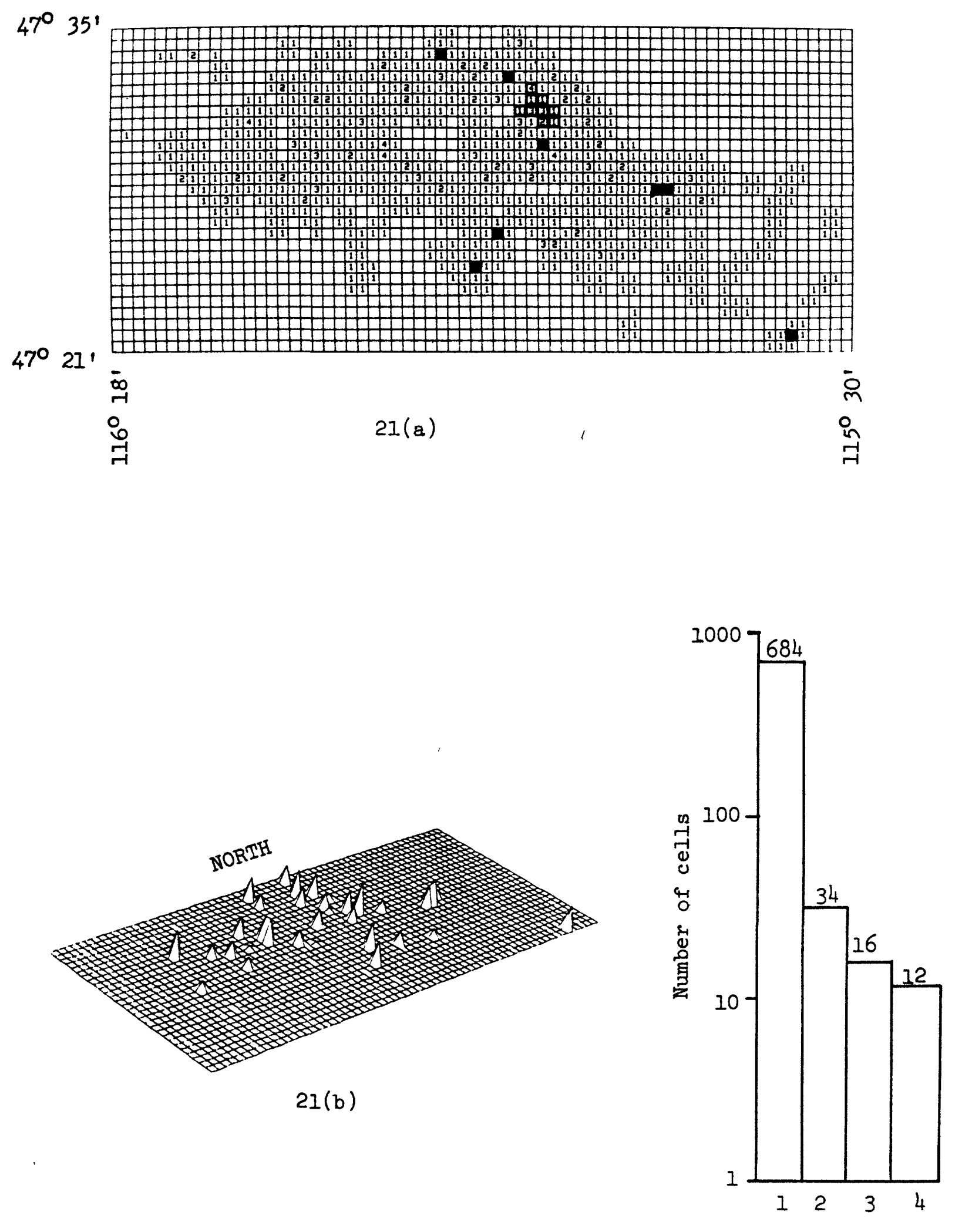

Contour level

$21(c)$ 
Figure 22. Degrees of association of the Coeur d' Alene mining district with the aggregate mineralization model area.

a. Plan map showing distribution of degrees of association of the entire district with the model area. Model cells are doubly outlined. Solid cells are non-aggregate model anomalies.

b. Perspective drawing of ' $a$ ' (above) showing only highest levels of association.

c. Frequency distribution of contour levels (exclusive of model). Level Explanat1on

1 Low degree of association between cell and model.

2 Low-moderate degree of association between cell and model.

3 Moderate-high degree of association between cell and model.

4 High degree of association between cell and model. blank No date. 

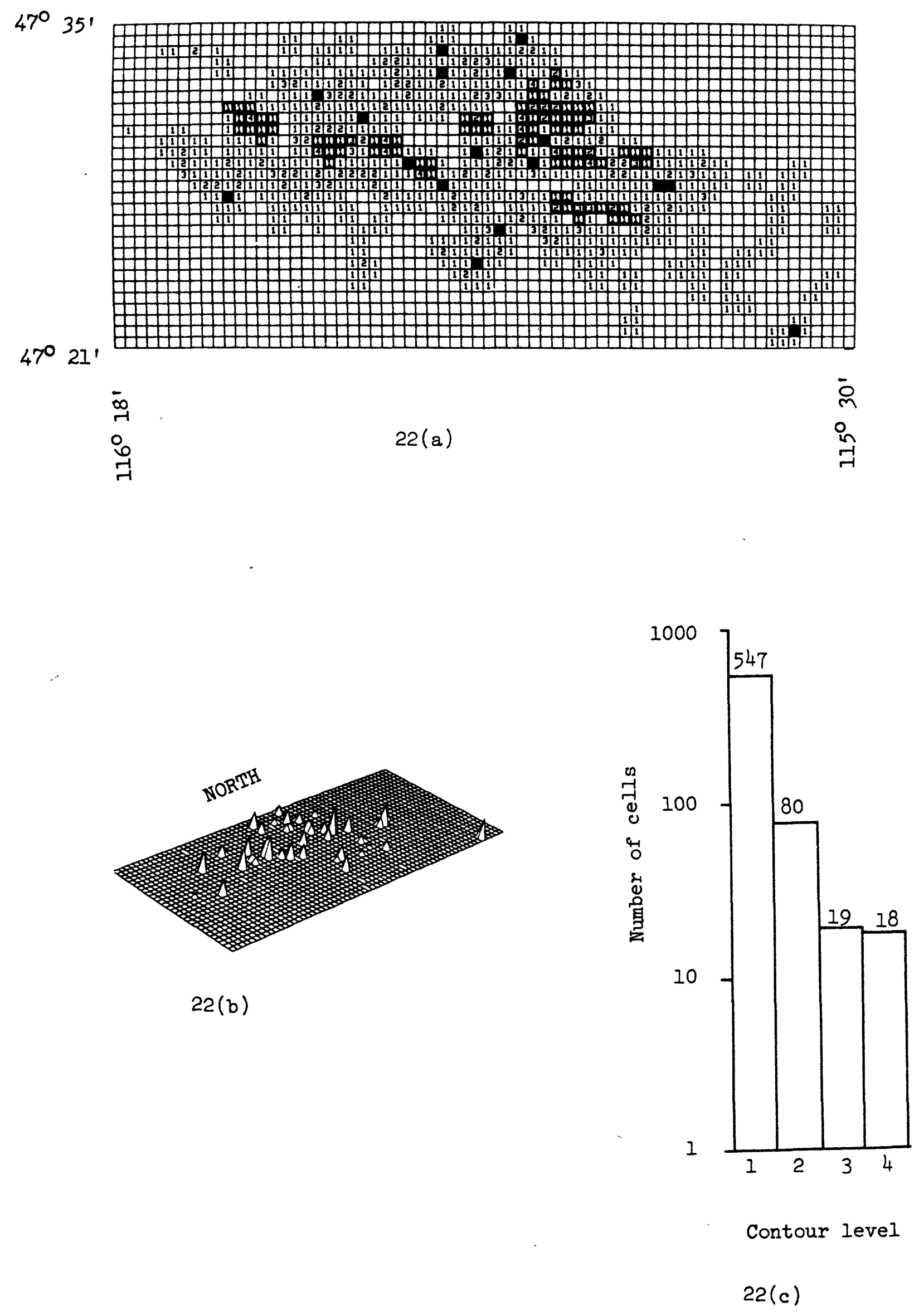


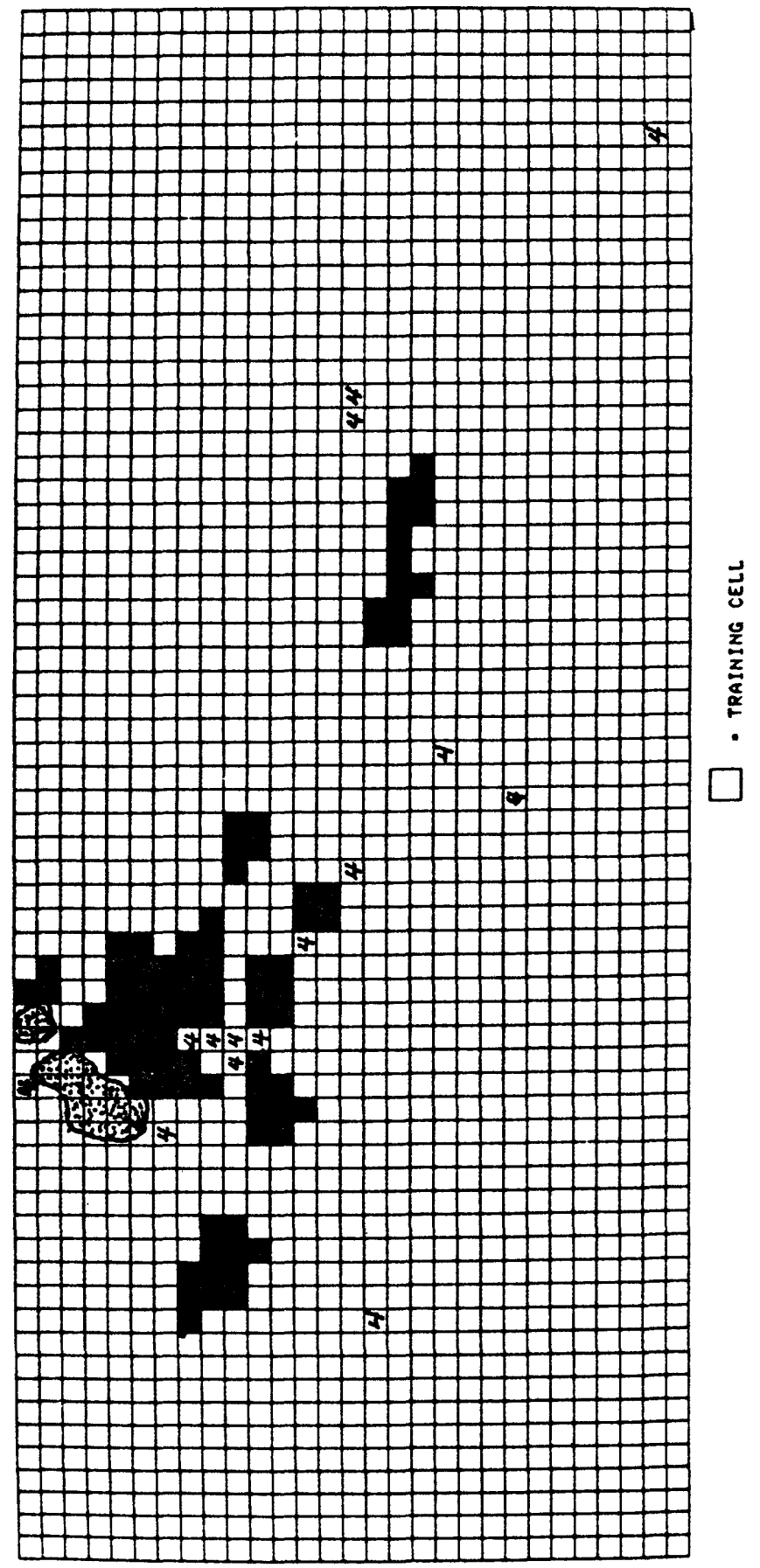

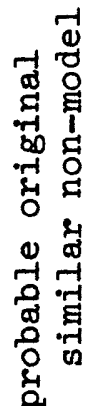

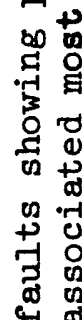

कू

도검

a

ฮี

:

ช్

국

t)

क्ष

ธี



政

Oे

足

i.

告

$\dot{\sim}$

ले 